\title{
El derecho a interponer recursos y a obtener reparación de los familiares de personas desaparecidas durante la guerra civil española*
}

\author{
The right of relatives of persons who \\ disappeared during the Spanish Civil War \\ to appeal and obtain redress
}

\author{
Margalida Capellà i Roig ${ }^{* *}$ \\ Universitat de les Illes Balears \\ ORCID ID 0000-0003-0830-2348 \\ margalida.capella@uib.cat
}

Cita recomendada:

Capellà i Roig, M. (2021). El derecho a interponer recursos y a obtener reparación de los familiares de personas desaparecidas durante la guerra civil española. Eunomía. Revista en Cultura de la Legalidad, 20, pp. 104-140.

doi: https://doi.org/10.20318/eunomia.2021.6065

Recibido / received: 15/05/2020 Aceptado / accepted: 22/01/2021

\section{Resumen}

Este estudio se centra en el derecho a reparación económica y el derecho a saber la suerte o el paradero de las personas civiles desaparecidas durante la Guerra Civil en España y a recuperar sus restos. El objetivo es explicar qué recursos existen en derecho español para que familiares de las víctimas civiles de las desapariciones relacionadas con la Guerra Civil y la represión franquista puedan reclamar una investigación judicial sobre los hechos acaecidos, la localización y exhumación de las personas desaparecidas y, además, una reparación del daño sufrido, en concreto por el trato inhumano y cruel infligido por acción o por omisión a estos familiares tanto durante los períodos mencionados como incluso en la actual democracia. Planteo si estos recursos son efectivos de acuerdo con los estándares internacionales y si la reparación prevista resulta adecuada, efectiva y rápida.

\footnotetext{
* Este trabajo se enmarca en el proyecto No PID2019-104418RB-100 «Más allá del subtierro: del giro forense a la necropolítica en las exhumaciones de fosas comunes de la guerra civil», del Ministerio de Ciencia e Innovación.

${ }^{* *}$ Profesora contratada doctora de Derecho Internacional Público.
} 


\title{
Palabras clave
}

Derecho internacional, reparaciones, derechos humanos, guerra civil española, personas desaparecidas, fosas comunes, franquismo, justicia de transición.

\begin{abstract}
This study focuses on the right to economic reparation and the right to know the fate or whereabouts of civilians who disappeared during the Civil War in Spain and to recover their remains. The objective is to explain what remedies exist in Spanish law so that relatives of the civilian victims of the disappearances related to the Civil War and Franco's repression can demand a judicial investigation into the events that occurred, the location and exhumation of the disappeared and, furthermore, a reparation for the damage suffered, specifically for the inhuman and cruel treatment inflicted by action or omission on these relatives both during the mentioned periods and even in the current democracy. I ask if these remedies are effective in accordance with international standards and if the planned remedy is adequate, effective and quick.
\end{abstract}

\section{Keywords}

International Law, reparations, remedies, Spanish Civil War, disappeared people, mass graves, Francoism, transitional justice.

\begin{abstract}
SUMARIO. 1. El derecho a reparación en el marco jurídico internacional. 2. La regulación jurídica de la situación de desaparición de civiles durante la Guerra Civil hasta la actual Ley 52/2007 «de memoria histórica». 2.1. Inscripción de desapariciones durante y tras la guerra en el registro civil. 2.2. Pensiones extraordinarias y reparaciones relacionadas con la guerra para familiares de desaparecidos. 2.3. Exhumaciones, censos de desaparecidos de la Guerra Civil y homenajes como formas de reparación. 3. Falta de acceso igual a un recurso efectivo. 3.1. La vía penal. 3.2. La vía civil. 4. Propuestas de reforma legislativa. 5. Conclusiones.
\end{abstract}

En los últimos años distintos órganos internacionales han dejado constancia de las carencias y de la ineficacia de las medidas estatales adoptadas en España en relación con las víctimas de desapariciones forzadas y su acceso a medidas de reparación y búsqueda de sus familiares ${ }^{1}$. Numerosos factores legales, históricos y políticos explican esta situación, pero en este artículo me centraré en uno que bajo mi punto de vista no se ha explicado suficientemente desde la perspectiva jurídica: el trato desigual o asimétrico que desde el principio de la Guerra Civil las autoridades franquistas infligieron a los familiares de desaparecidos en la retaguardia republicana mediante la llamada "legislación de guerra» y que tuvo como objetivo y como resultado anular el reconocimiento del derecho a reparación de estas personas, sin que a día de hoy cuenten con un remedio efectivo para resarcirse de la discriminación sufrida.

En este estudio desarrollaré en concreto los problemas, obstáculos e impedimentos que han tenido y tienen aún los familiares de desaparecidos en la inscripción de la desaparición, en la obtención de una reparación económica, en la

\footnotetext{
${ }^{1} \mathrm{NU}$ doc. A/HRC/27/56/Add.1, Informe del Relator Especial sobre la promoción de la verdad, la justicia, la reparación y las garantías de no repetición, Pablo de Greiff. Misión a España, de 22 de julio de 2014 (en adelante: Informe Relator, 2014); NU doc. A/HRC/27/49/Add.1, Informe del Grupo de Trabajo sobre las Desapariciones Forzadas o Involuntarias. Misión a España, de 2 de julio de 2014; NU doc. CED/C/ESP/CO/1, Observaciones finales sobre el informe presentado por España en virtud del artículo 29, párrafo 1, de la Convención, 12 de diciembre de 2013; NU doc. CCPR/C/ESP/6, Comité de Derechos Humanos, Observaciones finales sobre el sexto informe periódico de España, 14 de agosto de 2015.
} 
localización y exhumación de fosas comunes y en el acceso a un recurso efectivo por la vía penal y la vía civil. Me referiré al final al Anteproyecto de Ley de Memoria Democrática, una iniciativa legislativa anunciada en setiembre de 2020 pero que no ha sido registrada como proyecto de ley en el momento de cerrar este estudio ${ }^{2}$.

\section{El derecho a la reparación en el marco jurídico internacional}

El marco jurídico de este estudio se encuentra en el «derecho de las víctimas de violaciones de derechos humanos a la reparación». Este derecho se basa, en primer lugar, en la obligación internacional que asumen los Estados de respetar y aplicar las normas internacionales de derechos humanos cuando ratifican los tratados de derechos humanos. Las obligaciones asumidas por un Estado en virtud del derecho internacional de los derechos humanos y del derecho humanitario entrañan consecuencias jurídicas, no sólo con respecto a otros Estados sino también con respecto a personas individuales o grupos de personas sujetos a la jurisdicción de un Estado (Pisillo, 2003). Este deber de garantizar el disfrute efectivo de los derechos humanos requiere que el Estado adopte todas las medidas legislativas y de otro tipo necesarias para hacer efectivos los derechos garantizados en el derecho internacional, mediante todo su sistema legal, político e institucional, y para organizar el aparato gubernamental y, en general, todas las estructuras a través de las cuales se ejerce el poder público, de modo que sean capaces de garantizar legalmente el ejercicio libre y pleno de los derechos humanos ${ }^{3}$.

Brevemente, y a efectos de valorar las medidas adoptadas en España para garantizar el derecho a reparación de los familiares de personas desaparecidas en relación con la Guerra civil, hay que tener en cuenta que las diferentes obligaciones del Estado mencionadas en esta materia son complementarias y no alternativas (no pueden sustituirse entre sí), y además son incondicionales: es decir, aunque interrelacionadas, no dependen las unas de las otras, ni tampoco están condicionadas a una denuncia individual. Así, aunque las víctimas pueden renunciar a su derecho a la reparación, el Estado no puede, por ejemplo, eludir su obligación de investigar y llevar ante la justicia a los autores de graves violaciones de derechos humanos y ofrecer reparaciones en forma de pensiones e indemnizaciones: al tratarse de violaciones graves de derechos humanos el Estado tiene un deber no solo hacia las víctimas, sino también hacia la sociedad en general porque el deber de reparación contiene un elemento disuasorio encaminado a la prevención de futuras violaciones de derechos humanos ${ }^{4}$.

\footnotetext{
2 El Consejo de Ministros aprobó el Anteproyecto de Ley de Memoria Democrática el 15 de setiembre de 2020. Véase: La Moncloa (2020, 15 de setiembre) y Ministerio de la Presidencia, Relaciones con las Cortes y Memoria Democrática (2020). Se sometió a participación pública del 11 de noviembre al 3 de diciembre de 2020.

${ }^{3}$ Véase el reciente manual sobre reparaciones de la Comisión Internacional de Juristas que recoge ampliamente jurisprudencia de los comités de derechos humanos y de los tribunales regionales, así como del Tribunal Internacional de Justicia y de los tribunales penales internacionales especiales sobre las características de las reparaciones (International Comission of Jurists, 2018, pp. 15-31).

${ }^{4}$ Como concluía ya en 1993 el Relator Especial sobre ejecuciones extrajudiciales, sumarias y arbitrarias: «Según el derecho internacional, los gobiernos están obligados a llevar a cabo investigaciones exhaustivas e imparciales sobre las denuncias de violaciones del derecho a la vida, identificar, llevar ante la justicia y castigar a sus autores, otorgarles indemnización a las víctimas o sus familias, y tomar medidas efectivas para evitar la recurrencia futura de tales violaciones. Los primeros dos componentes de esta obligación cuádruple constituyen en sí mismos el elemento disuasorio más efectivo para la prevención de violaciones de derechos humanos. Por el contrario, si los perpetradores pueden estar seguros de que no serán considerados responsables, es probable que tales violaciones continúen sin cesar [...] Otorgar una indemnización presupone el cumplimiento de la obligación de llevar a cabo una investigación sobre las denuncias de abusos contra los derechos humanos con el fin de identificar y procesando a sus perpetradores. Sin embargo, las compensaciones financieras o de otro tipo otorgadas
} 
En segundo lugar, el derecho a la reparación se incluye en el derecho de las víctimas a un remedio o recurso efectivo cuando se produce una violación de derechos humanos, así es como se reconoce en tratados como el Pacto Internacional de Derechos Civiles y Políticos (artículo 2.3), la Convención Internacional sobre la Eliminación de Todas las Formas de Discriminación Racial (artículo 6), la Convención contra la Tortura y Otros Tratos o Penas Crueles, Inhumanos o Degradantes (artículo 14) o la Convención sobre los Derechos del Niño (artículo 39). En el ámbito del derecho internacional humanitario y el derecho penal internacional también prevén la reparación el Convenio de La Haya relativo a las leyes y usos de la guerra terrestre (artículo 3), el Protocolo Adicional a los Convenios de Ginebra del 12 de agosto de 1949 relativo a la protección de las víctimas de los conflictos armados internacionales (artículo 91) y, asimismo, el Estatuto de Roma de la Corte Penal Internacional (artículos 68 y 75 ).

La jurisprudencia internacional ha sido clave en el desarrollo de los aspectos relacionados con la obligación de los Estados de garantizar la reparación. Aunque la interpretación y la terminología difieren de un sistema a otro, a menudo por cuestiones lingüísticas (por ejemplo el sentido más amplio del término "remedy» en inglés respecto del equivalente «recurso» en español), es posible identificar un conjunto coherente de principios sobre el derecho a recurso y reparación que ha sido sistematizado en los «Principios y directrices básicos sobre el derecho de las víctimas de violaciones manifiestas de las normas internacionales de derechos humanos y de violaciones graves del derecho internacional humanitario a interponer recursos y obtener reparaciones» ${ }^{5}$ (en adelante "Principios de 2005 sobre recursos y reparaciones»). Preparados por la Comisión de Derechos Humanos de las Naciones Unidas y aprobados por la Asamblea General en 2005, dichos Principios son una referencia obligada cuando en el caso español planteamos la obligación de respetar, asegurar que se respeten y aplicar las normas internacionales de derechos humanos y el derecho internacional humanitario.

Esta obligación comprende, entre otros, el deber de:

a) Adoptar disposiciones legislativas y administrativas $y$ otras medidas apropiadas para impedir las violaciones;

\begin{abstract}
a las víctimas o sus familias antes de que se inicien o concluyan tales investigaciones, no eximen a los gobiernos de esta obligación [...] El Relator Especial insta a los Estados a que introduzcan en la legislación nacional las disposiciones pertinentes y destinen fondos para quienes hayan sufrido daños como consecuencia de ejecuciones extrajudiciales, sumarias o arbitrarias». NU doc. E/CN.4/1994/7 (1994), Informe del Relator Especial, Sr. Bacre Waly Ndiaye, presentado en cumplimiento de la resolución 1993/71 de la Comisión de Derechos Humanos, de 7 de diciembre de 1993, pár. 688 y 711.

${ }^{5} \mathrm{NU}$ doc. A/RES/60/147, «Principios y directrices básicos sobre el derecho de las víctimas de violaciones manifiestas de las normas internacionales de derechos humanos y de violaciones graves del derecho internacional humanitario a interponer recursos y obtener reparaciones», de 21 de marzo de 2006. Además, NU doc. E/CN.4/2005/102/Add.1, «Conjunto de principios actualizado para la protección y la promoción de los derechos humanos mediante la lucha contra la impunidad», de 18 de febrero de 2005. Estos instrumentos corresponden a los estándares internacionales a que me refiero a lo largo de este estudio, que deben completarse con la jurisprudencia y las decisiones posteriores a 2005 de los órganos de derechos humanos. En el ámbito de la justicia de transición en el que cabe analizar las medidas de reparación adoptadas en España teniendo como referencias otras experiencias de transición, es relevante también el primer informe del Secretario General de la ONU sobre el Estado de derecho y la justicia de transición en las sociedades que sufren o han sufrido conflictos, porque permite situar la cuestión de la justicia de transición, o el recurrente dilema «¿paz o justicia?» (o «reconciliación o justicia» en el caso español), dentro del concepto y las exigencias del Estado de derecho. Véase: NU doc. S/2004/616, «informe del Secretario General de la ONU sobre el Estado de derecho y la justicia de transición en las sociedades que sufren o han sufrido conflictos», de 3 de agosto de 2004, y sus posteriores desarrollos.
\end{abstract}


b) Investigar las violaciones de forma eficaz, rápida, completa e imparcial y, en su caso, adoptar medidas contra los presuntos responsables de conformidad con el derecho interno e internacional;

c) Dar a quienes afirman ser víctimas de una violación de sus derechos humanos o del derecho humanitario un acceso equitativo y efectivo a la justicia, como se describe más adelante, con independencia de quién resulte ser en definitiva el responsable de la violación; y

d) Proporcionar a las víctimas recursos eficaces, incluso reparación.

Entre los recursos eficaces contra las violaciones manifiestas de las normas internacionales de derechos humanos y las violaciones graves del derecho internacional humanitario figuran el derecho de acceso igual y efectivo a la justicia; el derecho a una reparación adecuada, efectiva y rápida del daño sufrido; y el derecho de acceso a información pertinente sobre las violaciones y los mecanismos de reparación. Los recursos no solo deben ser eficaces, sino también adecuados, y rápidos, han de comprender todos los procedimientos internacionales disponibles y apropiados a los que tenga derecho una persona y no deberían redundar en detrimento de ningún otro recurso interno ${ }^{6}$.

Tres cuestiones me parecen básicas para situar el problema de las reparaciones que nos ocupa.

En primer lugar, hay que entender el término «recurso eficaz» en su doble dimensión procedimental y substantiva en el sentido más amplio de remedio («remedy» en inglés) o resarcimiento: cabe referirnos tanto al remedio procedimental (derecho a un recurso judicial) como al remedio sustantivo (el derecho a una reparación en sí, mediante restitución, indemnización, rehabilitación, satisfacción y garantías de no repetición) (Shelton, 2005; International Comission of Jurists, 2018, p. xii). La dimensión procesal se subsume en el concepto de la obligación de proporcionar «recursos internos efectivos», explícito en la mayoría de los instrumentos de derechos humanos. La reparación, por tanto, es un componente de los recursos internos efectivos y ello supone, como afirma el Comité de Derechos Humanos, que sin reparación, en caso de violación de los derechos humanos, no se cumple la obligación de proporcionar un recurso efectivo ${ }^{7}$.

En segundo lugar, también es necesario tener en cuenta que las diferentes formas de reparación mencionadas son complementarias y no alternativas entre si $i^{8}$, y de hecho lo que se prevé internacionalmente es la creación de un programa amplio de reparaciones, combinando y complementando las diferentes formas de reparación, pues un programa efectivo de reparación debe caracterizarse por su amplitud ${ }^{9}$. En todo caso, no cualquier reparación cumple los estándares internacionales, pues se debe tratar de una «reparación en forma adecuada» y que variará según cada caso

\footnotetext{
${ }^{6}$ Principios sobre recursos y reparaciones de 2005, pár. 14.

7 NU doc. CCPR/C/21/Rev.1/Add.13, Observación general n³1, Naturaleza de la obligación jurídica general impuesta a los Estados Partes en el Pacto, 26 de mayo de 2004.

8 En consonancia con el artículo 34 de los Artículos sobre Responsabilidad del Estado por hechos internacionalmente ilícitos, adoptados por la Comisión de Derecho Internacional, que establece que la reparación total deberá tomar la forma de restitución, compensación y satisfacción «individualmente o en combinación».

${ }_{9}$ NU doc. E/CN.4/2004/88 (2004). «Estudio independiente, con inclusión de recomendaciones, sobre las mejores prácticas, para ayudar a los estados a reforzar su capacidad nacional con miras a combatir todos los aspectos de la impunidad», de 27 de febrero de 2004, párr. 60.
} 
dependiendo de las circunstancias concretas que rodean cada caso y la naturaleza precisa y el alcance de la lesión ${ }^{10}$.

En tercer lugar, cabe precisar que el enjuiciamiento de los autores de violaciones graves de los derechos humanos también puede constituir en sí mismo una forma de reparación, en concreto una medida de satisfacción, y contribuye al derecho de las víctimas y sus familias a la verdad y a la lucha contra la impunidad como elemento de garantías. No obstante, el Estado tiene el deber de enjuiciar a los autores de violaciones graves de derechos humanos, independientemente de cualquier reclamo por reparación interpuesto por víctimas individuales.

Finalmente, hay que tener en cuenta que la reparación también deber ser adecuada, efectiva y rápida, además de proporcional a la gravedad de las violaciones $y$ al daño sufrido. Se deben conceder por las acciones u omisiones que puedan atribuirse al Estado y constituyan violaciones manifiestas de las normas internacionales de derechos humanos o violaciones graves del derecho internacional humanitario y se prevé que el Estado ha de procurar establecer programas nacionales de reparación y otra asistencia a las víctimas cuando el responsable de los daños sufridos no pueda o no quiera cumplir sus obligaciones ${ }^{11}$.

En los Principios de 2005 sobre recursos y reparaciones se establece también el contenido, las características y finalidades de las diferentes formas de reparación previstas $^{12}$, de los que destacaría, en el caso de las desapariciones que nos ocupan, la imposible restitución de la víctima a la situación anterior a la detención; la necesidad de que la indemnización sea apropiada y proporcional a la gravedad de la violación y a las circunstancias de cada caso, y de que se conceda por todos los perjuicios económicamente evaluables que sean consecuencia de violaciones manifiestas de las normas internacionales de derechos humanos o de violaciones graves del derecho internacional humanitario, tales como el daño físico o mental; la pérdida de oportunidades, en particular las de empleo, educación y prestaciones sociales; los daños materiales y la pérdida de ingresos, incluido el lucro cesante o los perjuicios morales. La rehabilitación ha de incluir la atención médica y psicológica, así como servicios jurídicos y sociales y la satisfacción ha de incluir, cuando sea pertinente y procedente, la totalidad o parte de las medidas siguientes:

a) Medidas eficaces para conseguir que no continúen las violaciones.

b) La verificación de los hechos y la revelación pública y completa de la verdad, en la medida en que esa revelación no provoque más daños o amenace la seguridad y los intereses de la víctima, de sus familiares, de los testigos o de personas que han intervenido para ayudar a la víctima o impedir que se produzcan nuevas violaciones.

c) La búsqueda de las personas desaparecidas, de las identidades de los niños secuestrados y de los cadáveres de las personas asesinadas, y la ayuda para recuperarlos, identificarlos y volver a inhumarlos según el

\footnotetext{
10 «El derecho a la reparación cubrirá todas las lesiones sufridas por la víctima; incluirá medidas individuales relativas al derecho de restitución, compensación y rehabilitación, y medidas generales de satisfacción según lo dispuesto por el derecho internacional». NU doc. E/CN.4/2005/102/Add.1, «Conjunto de principios actualizado para la protección y la promoción de los derechos humanos mediante la lucha contra la impunidad», cit., Principio 34.

${ }^{11}$ Principios de 2005 sobre recursos y reparaciones, párr. 17.

12 Ibídem, párrs. 19 a 23.
} 
deseo explícito o presunto de la víctima o las prácticas culturales de su familia y comunidad.

d) Una declaración oficial o decisión judicial que restablezca la dignidad, la reputación y los derechos de la víctima y de las personas estrechamente vinculadas a ella.

e) Una disculpa pública que incluya el reconocimiento de los hechos y la aceptación de responsabilidades.

f) La aplicación de sanciones judiciales o administrativas a los responsables de las violaciones.

g) Conmemoraciones y homenajes a las víctimas.

h) La inclusión de una exposición precisa de las violaciones ocurridas en la enseñanza de las normas internacionales de derechos humanos y del derecho internacional humanitario, así como en el material didáctico a todos los niveles.

Finalmente, las garantías de no repetición han de incluir, según proceda: medidas que contribuyan a la prevención, en este caso de las desapariciones forzadas, entre otras, el ejercicio de un control efectivo por las autoridades civiles sobre las fuerzas armadas y de seguridad; la garantía de que todos los procedimientos civiles y militares se ajusten a las normas internacionales relativas a las garantías procesales, la equidad y la imparcialidad, o la revisión y reforma de las leyes que contribuyan o permitan las violaciones manifiestas de las normas internacionales de derechos humanos y a las violaciones graves del derecho humanitario.

A continuación, explico cómo se han articulado en el derecho español los recursos y las reparaciones a familiares de desaparecidos durante la Guerra Civil y el franquismo. Empezaré con las dificultades que encontraron a partir de 1936 los familiares de desaparecidos por la represión franquista al inscribir la desaparición en los registros civiles. Posteriormente, indicaré las reparaciones económicas (pensiones) reguladas por la vía administrativa y los procedimientos administrativos para la localización de fosas comunes y recuperación de los cuerpos de los desaparecidos. Finalmente, trataré la respuesta que ha dado la justicia española y, por tanto, el ordenamiento jurídico español, ante la exigencia de reparación por la vía judicial.

2. La regulación jurídica de la situación de desaparición de civiles durante la Guerra Civil hasta la actual Ley 52/2007 «de memoria histórica»

Para los familiares de desaparecidos que no fueran afectos al régimen franquista ni personal civil, militar o combatiente en el bando franquista no existe ni ha existido un plan o programa nacional de reparaciones económicas (pensiones 0 indemnizaciones) de carácter integral, sino normativa escalonada, dispersa, sectorial, parcial, confusa, puramente asistencial y sin reconocimiento de los hechos como violaciones de derechos humanos (Tamarit, 2011, p. 740; Vallés, 2019, p. 28, 327; Baylos, 2008).

El punto de partida de este «tratamiento asimétrico», en términos del Relator especial sobre justicia de transición (Informe sobre España, 2014, párr. 6), es que la situación de las personas desaparecidas durante la guerra civil española fue tratada 
de forma diferente según la afinidad política del desaparecido, el lugar donde se produjo la desaparición (zona nacional o zona republicana), el carácter militar, combatiente, funcionario o civil de la persona desaparecida y, finalmente, su adhesión al golpe de estado y al régimen franquista.

Un estudio de la normativa específica aplicada a la situación de desaparición nos permite afirmar que los familiares de los desaparecidos en «zona nacional» que fueron víctimas de la represión franquista sufrieron un trato desigual durante y después de la guerra en tres momentos:

2.1. En la inscripción de la desaparición en el Registro Civil a efectos de la declaración de ausencia y de fallecimiento,

2.2. En las prestaciones o pensiones extraordinarias creadas durante y después de la guerra, sin que esta situación se haya solucionado en democracia, y finalmente

\subsection{En la búsqueda, localización y exhumación de las fosas comunes.}

\subsection{Inscripción de las desapariciones durante y tras la guerra en el Registro Civil}

En este apartado se explica por qué las familias de víctimas civiles de la represión franquista durante la guerra y la inmediata posguerra tardaron más que las de víctimas de la retaguardia republicana en inscribir desapariciones y conseguir la declaración de fallecimiento. Incluso recientemente, en la Disposición adicional octava de la Ley 20/2011, de 21 de julio, del Registro Civil, se ha tenido que continuar legislando cómo inscribir la defunción de las personas desaparecidas durante la Guerra Civil y la represión posterior para seguir eliminando los obstáculos que aún se encontraban en esa fecha.

La inscripción de la desaparición a efectos de la declaración de ausencia o de fallecimiento para la tramitación de expedientes de pensión a favor de las familias de los desaparecidos o, simplemente, para regularizar su fallecimiento a efectos legales, fue facilitada por las autoridades franquistas exclusivamente para las desapariciones de combatientes y de civiles víctimas de la retaguardia republicana. Las desapariciones en combate causadas por las tropas franquistas y por la represión franquista tuvieron un trato legal distinto desde el mismo momento de la inscripción en los registros civiles, a partir de sucesivas regulaciones que dejaron intencionadamente a cónyuges e hijos de las víctimas republicanas sin poder iniciar los trámites sucesorios ni acceder a prestaciones.

Una cronología de estas regulaciones permite apreciar el carácter progresivo, sistemático e intencionado del trato desigual de las víctimas «republicanas» civiles de desaparición forzada.

El Gobierno de la República reguló por el Decreto de 29 de agosto de 1936 un procedimiento específico para la inscripción del fallecimiento de militares, milicianos y paisanos ocurridos en campaña o de resultas de ésta pues la Ley provisional de 17 de junio de 1870 no preveía esta situación ${ }^{13}$. Este Decreto establece dónde se deben practicar las inscripciones de fallecimiento tanto de personas identificadas como de personas desconocidas o de hallazgos de cadáveres cuya identidad no era posible en aquel momento comprobar. Por esta regulación podemos encontrar descripciones muy detalladas de personas halladas muertas con signos de violencia en los asientos

\footnotetext{
${ }^{13}$ Gaceta de Madrid, $n^{\circ}$ 242. La Gaceta era el diario o boletín oficial del Gobierno republicano.
} 
de los registros civiles, muchas de las cuales sirvieron en su momento o bien actualmente para identificar personas desaparecidas.

En caso de desaparición, de la que daban cuenta, principalmente, los familiares, se debía seguir lo previsto en el Código Civil vigente entonces de 1889 (CC 1889) para la presunción de muerte de un ausente: debían pasar treinta años desde que la persona desapareció o se recibieron las últimas noticias de ella (art. 191 CC 1889).

En la zona llamada «nacional» se impulsó normativa desde el primer momento en que triunfó el golpe de estado. Parte de esta normativa se refirió a la situación de los fallecidos y desaparecidos durante la guerra, ya fueran combatientes o civiles, y a las pensiones reconocidas inmediatamente a favor de las familias del personal militar y del personal civil del Estado, de las provincias y de los municipios, a medida que se iban produciendo bajas especialmente en las filas militares «nacionales». A principios de la guerra se regularon unas primeras pensiones extraordinarias para las familias de los militares que se hubieran adherido al golpe militar y que hubieran desaparecido «cuando existían vehementes indicios de haber sido asesinados por los rebeldes con ocasión de prestar o por haber prestado servicios a la causa nacional» ${ }^{14}$. El problema que presentaba la solicitud y reconocimiento de estas pensiones era cómo acreditar la condición de desaparecido y desde qué momento podía surtir efectos la desaparición para la declaración de fallecimiento.

El Decreto $n^{\circ} 67$, de 8 de noviembre de 1936, del llamado «Gobierno de Burgos» (autoridades franquistas) reguló un procedimiento especial para la inscripción de fallecimiento o desaparición de personas, fueran o no combatientes, durante la guerra que se estaba desarrollando en ese momento y, además, estableció como plazo de presunción de muerte cinco años después de la inscripción de los desaparecidos a los efectos del artículo 191 CC 1889 indicado ${ }^{15}$.

Dos días después, la Junta Técnica del Estado emitió unas reglas para la aplicación de dicho decreto que sentaron las bases de la posterior discriminación, escasamente documentada por historiadores y juristas y que se aplicó durante años. Se empezó distinguiendo entre inscripción de defunción y de desaparición en el Registro Civil. Si se trataba de un fallecimiento acreditado judicialmente, el juez competente dictaba auto ordenando la inscripción de defunción y producía los efectos de una defunción ordinaria y no se debían esperar los cinco años previstos en el Decreto $n^{\circ} 67$. Si no se podía acreditar el fallecimiento, se inscribía la desaparición (en una nota marginal) y esta producía los efectos jurídicos de una declaración de ausencia y cinco años después se podía declarar la presunción de fallecimiento ${ }^{16}$.

Pero además esta Orden, de 10 de noviembre de 1936, puede servir parar probar el carácter sistemático de la represión franquista, porque queda patente que se confeccionaban listas de desaparecidos, que después se entregaban al juez para que quedara constancia en el Registro Civil a efectos de agilizar la tramitación de la defunción en unos casos. La Orden establecía que podían instar la incoación de la inscripción de fallecimiento o desaparición el cónyuge, los parientes hasta el cuarto grado, los interesados patrimonialmente, y también «los jefes de fuerzas militares o

\footnotetext{
${ }^{14}$ Decreto $\mathrm{n}^{\circ} 24$ de 13 de octubre de 1936 (Boletín Oficial del Estado, Burgos, 17 de octubre de 1936, nº 4).

${ }^{15}$ Boletín Oficial del Estado (BOE), Burgos, 11 de noviembre de 1936, $n^{\circ} 27$. Este era el diario oficial del Gobierno franquista, su denominación se ha mantenido en democracia.

${ }^{16}$ Orden de la Presidencia de la Junta Técnica del Estado de 10 de noviembre de 1936, dictando reglas para la aplicación del Decreto $n^{\circ} 67$ sobre inscripción de fallecidos o desaparición, BOE $n^{\circ} 29$, de 13 de noviembre de 1936, rectificada el 16 de agosto de 1939 (BOE n² 275, p. 5519).
} 
militarizadas». Estas fuerzas militarizadas eran los grupos de falangistas que actuaban impunemente en la zona nacional. Los estragos de sus acciones pueden seguirse en los registros civiles mediante las inscripciones de fallecimiento y desaparición ya que, a pesar de la situación de guerra, los registros civiles no se pararon. Es frecuente por ello encontrar inscripciones de desaparición correlativas en el mismo libro de defunciones del Registro Civil y que corresponden a las «relaciones de individuos a sus órdenes [a las órdenes de los jefes de fuerzas militares o militarizadas] que hubiesen desaparecido» como establecía la Orden de 10 de noviembre. Estas listas debían ser enviadas por los jefes de estas fuerzas militarizadas, es decir, por los grupos de Falange (en nuestros días: grupos paramilitares) a los jueces de primera instancia o alcaldes, que debían remitirla a su vez en el plazo máximo de cinco días al juez de primera instancia del partido judicial. Finalmente, era el juez del domicilio u origen del presunto muerto o desaparecido quien dictaba auto aprobando o no la información practicada y ordenando en su caso la inscripción de la defunción en el Registro si estaba acreditada. Si solo estaba acreditada la desaparición (y la prueba era la relación enviada por el jefe de las fuerzas militares o militarizadas) se mandaba inscribir la desaparición en aquel registro.

En julio de 1939 comenzó la discriminación por razones políticas en el Registro Civil, porque se previó que las inscripciones de desaparición podían producir los efectos de una inscripción de defunción a los cinco años o incluso sin esperar a los cinco años previstos en el Decreto $n^{\circ} 67$, siempre que se refirieran al «Glorioso Alzamiento Nacional»: con el objeto de evitar «la posibilidad de que los expedientes se refieran en algún caso a personas desafectas al Glorioso Alzamiento Nacional, huidas del territorio patrio». La siguiente Orden de 26 julio de 1939 del Ministerio de Justicia estableció la obligación de los jueces de exigir antes de ordenar la inscripción de desaparición «una prueba de antecedentes que robustezca la garantía de que en el desaparecido no existe justificación patriótica para que, si vive, no haya dado noticias de su existencia» ${ }^{17}$. Solo las inscripciones de desaparición que incluyeran esta prueba y que no hubieran sido impugnadas judicialmente podían producir los efectos previstos en el Decreto de 8 de noviembre de 1936, que consistían en normalizar las relaciones patrimoniales (abrir la sucesión) y familiares (condición de viudas/os y huérfanos/as a efectos de solicitar pensión y otros) con el plazo general de cinco años que, con la Orden de julio de 1939, pasó a aplicarse solamente a la inscripciones de desaparecidos afectos al régimen franquista.

Al acabar la guerra, el Gobierno franquista modificó la declaración de ausencia y fallecimiento en el Código Civil (Ley de 8 de setiembre de 1939) para hacer frente a la gran cantidad de personas desaparecidas y estableció nuevos plazos, que se han mantenido prácticamente hasta la actualidad ${ }^{18}$. Sin embargo, en los registros civiles se siguió aplicando el mencionado Decreto nº 67 de 11 de noviembre de 1936 con

\footnotetext{
${ }^{17}$ BOE $n^{\circ} 222$, p. 4353. Por esta Orden de 26 de julio de 1939 los familiares de desaparecidos afectos a la causa franquista podían tramitar el expediente de defunción y éste se hacía efectivo automáticamente desde el momento de la inscripción sin esperar a los cinco años. El argumento era que los cinco años tenían sentido si el desaparecido residía en zona roja y no podía volver a "zona nacional», con lo que aún había esperanzas de que volviera, pero «lograda la unidad de España», si el desaparecido no se había reintegrado a su domicilio ni dado noticias de su actual paradero podía ser dado por muerto. En cambio, si se trataba de un desaparecido no afecto a la causa franquista, víctima de la represión franquista, los jueces exigían a los familiares, antes de ordenar la inscripción, una prueba que garantizara que el desaparecido había fallecido o bien esperar cinco años para inscribir la ausencia como defunción. 18 A grandes rasgos: 10 años desde las últimas noticias del ausente o, a falta de estas, desde su desaparición; 5 años si el ausente hubiera cumplido 75 años; 2 años si en la fecha de su desaparición existía un riesgo inminente de muerte por causa de siniestro o de violencia contra la vida, entendiendo como violencia una subversión del orden político y social; 2 años en caso de militares y combatientes en operaciones de campaña.
} 
una importante modificación introducida por la Orden de 10 de agosto de 1939: los expedientes de desaparición durante la guerra iban a producir los efectos normales de toda inscripción de defunción «siempre que se refieran a personas afectas al Glorioso Alzamiento Nacional, a cuyo fin los Jueces de primera instancia comprobarán ese extremo en la tramitación de los oportunos expedientes». Si no se trataba de personas afectas al régimen, una vez transcurridos cinco años desde la inscripción, el juez a instancia de parte podía declarar la presunción de muerte, siempre que estuviera documentada e informada convenientemente.

La Orden de 10 de agosto de 1939 del Ministerio de Justicia posibilitó que las inscripciones de defunción fuera de plazo continuaran efectuándose sin tener que esperar los cinco años preceptivos, siempre que se refirieran «a personas afectas al Glorioso Movimiento Nacional» ${ }^{19}$. Incluso dos años después se siguió aplicando este procedimiento especial, pues, por Orden de 12 de agosto de 1941, se abrió un nuevo plazo de seis meses para promover expedientes de inscripción de desaparecidos o fallecidos, siempre que se pudiera presentar «la prueba exigida por la Orden de este Ministerio de 27 de abril de 1940, al objeto de hacer constar en el cuerpo de las actas de defunción haber muerto gloriosamente por Dios y por España». Finalmente, en mayo de 1942 una última prórroga establecía que, hasta nueva disposición en contrario, se podían promover expedientes de inscripción de desaparecidos o fallecidos con arreglo al mencionado Decreto de 8 de noviembre de 1936 «al objeto de hacer constar en el cuerpo de las actas de defunción haber muerto gloriosamente por Dios y por España» ${ }^{20}$.

El resultado de esta normativa es que solo pudieron beneficiarse de estos plazos los familiares de quienes habían ganado la guerra. Ello causó un grave perjuicio a cónyuges, hijos/as y padres/madres de personas desaparecidas que no pudieron acreditar ni beneficiarse tampoco de su condición de viudos/viudas, huérfanos o padres de fallecidos hasta mucho más tarde. Así, por ejemplo, los hijos de desaparecidos que habían "perdido la guerra» no fueron considerados legalmente como huérfanos ni siquiera para beneficiarse del Fondo de protección benéfico-social creado por Decreto de 23 de noviembre de 1940 sobre protección del Estado a los huérfanos de la Revolución nacional y de la Guerra, la primera norma dictada por las autoridades franquistas que no requería adhesión a su causa.

Este procedimiento de inscripción de desaparecidos fue, además, un mecanismo facilitador de indemnizaciones o pensiones extraordinarias a favor de familiares de personas desaparecidas que fueran afectas al nuevo régimen franquista. Los familiares de los desaparecidos civiles del bando republicano no percibieron ninguna reparación hasta la aprobación de la Ley 5/1979, aunque, como se explicará más adelante, esta reparación no fue absoluta, ni integral ni efectiva en los casos de desaparición.

Por último, cabe destacar que en 2011 se volvió a modificar la inscripción de desaparecidos en el Registro Civil haciendo mención expresa a las personas

\footnotetext{
${ }^{19}$ BOE núm. 222, de 10 de agosto de 1939.

20 BOE de 3 de mayo de 1942, p. 3124 . Véase también la Orden de 29 de abril de 1940 por la que Gobierno franquista modificó el artículo 85 de la Ley del Registro Civil: en todas las inscripciones en el Registro Civil relativas a personas asesinadas o cuya muerte fuese debida a la ejecución de sentencia dictada por las llamadas autoridades o tribunales marxistas; por fallecimiento durante su cautiverio; por heridas o enfermedades contraídas en los frentes de combate, formando parte del "Ejército sublevado", se hacía constar por nota marginal «Muerto gloriosamente por Dios y por España». Las pruebas para inscribir esta consigna eran documentadas por las personas que solicitaban la inscripción y los jueces encargados del Registro Civil debían comprobar la certeza y veracidad de la defunción recabando información de las autoridades militares, la autoridad gubernativa, el jefe de puesto de la Guardia Civil, y el jefe local de FET y de las JONS de la localidad del fallecido.
} 
desaparecidas durante la Guerra Civil y la dictadura y eliminando el requerimiento de declaración judicial para la declaración de fallecimiento en esos casos. En concreto, la Disposición adicional octava de la Ley 20/2011, de 21 de julio, del Registro Civil ${ }^{21}$ bajo el título «Inscripción de defunción de desaparecidos durante la Guerra Civil y la dictadura» estableció que:

El expediente registral, resuelto favorablemente, será título suficiente para practicar la inscripción de la defunción de las personas desaparecidas durante la Guerra Civil y la represión política inmediatamente posterior, siempre que, de las pruebas aportadas, pueda inferirse razonablemente su fallecimiento, aunque no sean inmediatas a éste. En la valoración de las pruebas se considerará especialmente el tiempo transcurrido, las circunstancias de peligro y la existencia de indicios de persecución o violencia.

Esta modificación era necesaria pues el propio Ministerio de Justicia consideraba en ese año que «acreditar certeza de la muerte que excluyera cualquiera duda racional», por ejemplo, mediante testigos o documentos oficiales, que es lo que exigía el artículo 278.1 del Reglamento del Registro Civil entonces sin tener en cuenta la situación de la anterior Guerra Civil o de un contexto semejante, era «un procedimiento judicial en expediente de jurisdicción voluntaria, largo y costoso». En cambio, los expedientes de registro civil son gratuitos. Se consideró que sería suficiente la tramitación de un expediente administrativo y no acudir a la vía judicial por estos motivos ${ }^{22}$. Como se verá, esta consideración del Ministerio de Justicia sobre el carácter largo y costoso de la jurisdicción voluntaria no ha sido tenida en cuenta por el Tribunal Supremo en su sentencia de 28 de marzo de 2012 en la que dirige a los familiares de desaparecidos a la jurisdicción voluntaria para obtener una reparación consistente en la declaración judicial de la desaparición y la exhumación de los restos de la persona desaparecida, a pesar de que, efectivamente, es un recorrido largo y costoso económicamente.

Esta última modificación refleja la dificultad que aún encontraban en esta fecha reciente los familiares de desaparecidos que aún no habían inscrito la defunción de personas desaparecidas, o bien que ni tan solo habían inscrito su desaparición durante la guerra o en la inmediata posguerra, todo ello como resultado del trato desigual que se instauró en 1936.

2.2. Pensiones extraordinarias y reparaciones relacionadas con la guerra para familiares de desaparecidos

Durante la guerra, en la zona nacional se dictaron disposiciones especiales en materia de pensiones extraordinarias para familiares de personal militar o civil fallecido o desaparecido, tanto del Estado como de las provincias y los municipios ${ }^{23}$. Para casos

\footnotetext{
${ }^{21}$ BOE núm. 175, de 22/07/2011. En la anterior Ley de 8 de junio de 1957 sobre el Registro Civil, BOE núm. 151, de 10 de junio de 1957 se establecía en el artículo 86: "Será necesaria sentencia firme, expediente gubernativo $u$ orden de la autoridad judicial que instruya las diligencias seguidas por muerte violenta, que afirmen sin duda alguna el fallecimiento, para inscribir éste cuando el cadáver hubiere desaparecido o se hubiere inhumado antes de la inscripción».

${ }^{22}$ Artículo 278 del Reglamento del Registro Civil. «Cuando el cadáver hubiera desaparecido o se hubiera inhumado no basta para la inscripción la fama o posibilidad de muerte, sino que se requiere certeza indudable. En su caso, a la orden de la Autoridad Judicial que instruye las diligencias seguidas por la muerte, debe haber precedido informe favorable del Ministerio Fiscal, y si se trata de Autoridad Judicial militar, el del Auditor; si la Autoridad Judicial es extranjera, se instruirá para poder inscribir el oportuno expediente. Para precisar las circunstancias en el expediente o diligencias se tendrán en cuenta las pruebas previstas para el de reconstitución».

${ }^{23}$ Decreto de 2 de diciembre de 1936, BOE del 9 de diciembre; Decreto de 13 de octubre de 1936, BOE del 17 de octubre; Decreto de 8 de mayo de 1938, BOE del mismo día; Decreto de 18 de abril de 1938 (BOE de 23 de abril) por la que se concedieron pensiones extraordinarias a las viudas y huérfanos de los militares sublevados muertos en el cautiverio.
} 
que no se encontraban entre estos supuestos generales, por ley se fueron concediendo individualmente pensiones extraordinarias a viudas de civiles afectos a la causa franquista fallecidos en el campo de batalla o defendiendo la causa nacional. Después de la guerra se crearon más pensiones extraordinarias siempre relacionadas con la guerra y el bando vencedor, así como, por ejemplo, pensiones en favor de padres pobres de sacerdotes muertos a consecuencia de la guerra, equiparados a funcionarios civiles. Las pensiones cubrían el $100 \%$, el $50 \%$ o el $25 \%$ del sueldo del causante ${ }^{24}$

En general, las familias de desaparecidos que no eran personal civil o militar no percibieron ninguna reparación económica, ni tampoco las familias de desaparecidos civiles que pudieran ser afectos al golpe de estado o al régimen franquista. Sin embargo, las familias de desaparecidos «no afectos al régimen franquista» no tuvieron las mismas facilidades que las familias «afectas al régimen» a la hora de tramitar la declaración de fallecimiento tras la inscripción de desaparición, al no constar como causa de la desaparición una inscripción referida a la guerra, a las «hordas marxistas» o al "Glorioso Movimiento Nacional». Sin esta referencia, de marcado carácter político, las familias de desaparecidos no afectos al régimen franquista no se atrevían a iniciar el expediente de defunción al haber transcurrido cinco años desde la inscripción de la desaparición, como preveía el Decreto $n^{\circ} 67$ de 1936 ni tampoco los dos años establecidos en el Código Civil reformado en 1939 para el supuesto de riesgo inminente de muerte por causa de violencia contra la vida. Se esperaba al plazo de diez años desde las últimas noticias del ausente o, a falta de estas, desde la inscripción de su desaparición o bien, si no era necesario a efectos de sucesión u otros aspectos legales, no se tramitaba la declaración de fallecimiento.

Por su parte, las familias de fallecidos y desaparecidos del bando franquista pudieron beneficiarse de pensiones extraordinarias, en el caso de familiares de personal militar y personal funcionario civil, o bien, en todos los casos, de facilidades para inscribir la desaparición y conseguir la presunción de fallecimiento incluso sin esperar necesariamente los cinco años prescritos en el Decreto $n^{\circ} 67$ de 1936. Asimismo, al finalizar la guerra se aprobó el acceso preferente a la función pública por parte de mutilados, ex combatientes y ex cautivos, así como a familiares de las víctimas de guerra («huérfanos y otras personas dependientes de las víctimas de la guerra y de los asesinados por los rojos») reservándoles el $80 \%$ de las vacantes existentes en las categorías inferiores de las plantillas de los diferentes servicios administrativos ${ }^{25}$. Entre estas "víctimas de guerra» no se incluyeron a las víctimas republicanas entonces ni en ningún momento de la dictadura franquista.

En los primeros años de la Transición se desarrolló normativa de forma escalonada y sectorial reconociendo pensiones y otras medidas de reparación a favor de las víctimas del franquismo y de la Guerra Civil ${ }^{26}$ pero el resultado de este proceso administrativo de reparaciones es disperso e incoherente, no existe un plan o programa general de reparaciones ni tampoco un texto refundido que unifique toda la normativa vigente y expulse la normativa y las pensiones derogadas (Vallès, 2019,

\footnotetext{
${ }^{24}$ Ley de 11 de junio de 1941, BOE del 6 de junio; Ley de 16 de junio de 1942, BOE del 3 de junio; Ley de 31 de diciembre de 1941, BOE del 15 de enero; Ley de 13 de diciembre de 1940 por la que se concede pensión extraordinaria a los padres de los militares muertos en el cautiverio y a los familiares de los muertos en lucha o ejecutados por negarse a servir en el ejército rojo, BOE $n^{\circ} 364,13$ de diciembre de 1940 , p. 8947.

${ }^{25}$ Ley de 25 de agosto de 1939, BOE de 1 de septiembre.

${ }^{26}$ El inicio de esta normativa se sitúa en el Real Decreto-ley 35/1978, de 16 de noviembre, por el que se conceden pensiones a los familiares de los españoles fallecidos como consecuencia de la guerra 19381939. Los supuestos no cubrían las desapariciones de civiles, se referían a muertos en acciones bélicas o como consecuencia de las heridas en campaña que no tuvieran reconocidas pensiones por la misma causa. Se derogó por Ley 5/1979, de 18 de septiembre, más amplia.
} 
pp. 327-335). En todo caso, las medidas legislativas reparadoras iniciales no declararon la ilegitimidad de los actos represivos del franquismo y de la rebelión militar, sino más bien se encaminaron a considerar legítimo al régimen republicano para que se pudieran generar efectos jurídicos en el ordenamiento vigente para aquellas personas que sirvieron como funcionarios o combatieron al servicio de la República durante los años de la Guerra Civil. Se distinguió, a estos efectos, entre causantes que fueran personal civil o militar o combatiente y causantes que hubieran fallecido o hubieran desaparecido y no tuvieran ninguna de estas condiciones.

La Ley 5/1979, de 18 de setiembre, sobre reconocimiento de pensiones, asistencia médico-farmacéutica y asistencia social en favor de las viudas, hijos y demás familiares de los españoles fallecidos como consecuencia o con ocasión de la pasada Guerra Civil fue la primera ocasión en la que el Estado, ya en democracia, facilitó la inscripción en el Registro Civil de personas fallecidas durante la guerra en el bando republicano (principalmente soldados), para que las viudas y huérfanos pudieran acogerse a la Ley y cobrar una pensión ${ }^{27}$.

El supuesto de los desaparecidos está regulado en el artículo primero de dicha Ley con la previsión de que causan derecho a pensión los desaparecidos en el frente o en otro lugar cuando pueda establecerse una presunción de fallecimiento por las causas enunciadas en los párrafos uno b) y dos b) del mismo artículo, a saber: por condena, acción violenta o en situación de privación de libertad, tanto durante como después de la guerra (a pesar de que la mayoría de desapariciones se produjeron durante la guerra).

Es posible también que familiares de desaparecidos que hubieran conseguido la declaración de fallecimiento por presunción de muerte hubieran solicitado estas pensiones acogiéndose a los supuestos de fallecimiento después de la guerra (apartado Dos del artículo 1 de la Ley), pues la fecha de la declaración de fallecimiento sería posterior a la finalización de la guerra por las razones explicadas. Sin embargo, la Ley 5/1979 restringe la aplicación del precepto a combatientes, mientras que en caso de civiles se exige que el fallecimiento se debiera a opinión política o sindical, una relación de causalidad entre la Guerra Civil y el fallecimiento, y que el fallecimiento no hubiera sido consecuencia de ejecución de sentencia ni derivado de acción violenta del propio causante.

No pudieron ser beneficiarios de esta pensión las viudas y los huérfanos de los civiles ejecutados por pena de muerte, los que habían muerto en la cárcel o en la comisaría, los que habían sufrido una ejecución extrajudicial y fueron asesinados por la policía franquista o por los fascistas; entre ellos también había personas desaparecidas.

\footnotetext{
${ }^{27}$ Se permitió la inscripción fuera de plazo, con carácter gratuito y con medios de prueba generales. Artículo 5. «Los que se consideren con derecho a las pensiones que esta Ley establece lo solicitarán acompañando a tal efecto la documentación que estimen pertinente para fundamentar su derecho. A tal fin se aceptarán cualesquiera de los medios de prueba admitidos en derecho. Los titulares de los Registros Civiles deberán facilitar a los eventuales beneficiarios que lo soliciten copia literal del Acta de Defunción del causante, y, en caso de que no constara en el Registro, procederán a la inscripción fuera de plazo de acuerdo con las disposiciones de la Ley de Registro Civil, todo ello con carácter gratuito. Asimismo, los Secretarios de los Juzgados y Tribunales de la jurisdicción civil y militar deberán extender las certificaciones de sentencia relativas a los causantes que sean solicitadas por los eventuales beneficiarios. (...)» Las solicitudes debían presentarse en el plazo de dos años y se preveía que el derecho no decaía pasado este plazo, aunque los efectos económicos de la pensión, en caso de ser reconocida, solo tendrían vigencia desde la solicitud de la pensión.
} 
La Ley 52/2007 eliminó estas restricciones, pero las pensiones reconocidas no tienen efectos retroactivos (a 1980), sino que surten efectos económicos solo a partir de 2008.

En todo caso, los beneficiarios de estas pensiones de la Ley 5/1979 están sujetos a criterios muy restrictivos, que no tienen que ver con su condición de víctimas de violaciones de derechos humanos o del derecho humanitario, sino con su vulnerabilidad al faltar o al haber faltado durante más de cuarenta años la figura del padre de familia, fallecido o desaparecido durante la guerra o en relación con la guerra. Los supuestos beneficiados eran pocos y fueron interpretados restrictivamente, lo que implicó que el número de beneficiarios fuera menor que el número probable de casos reales.

Según el Informe de la Comisión ministerial para el estudio de la situación de las víctimas de la Guerra Civil y el franquismo, de 28 de julio de 2006, se otorgaron 110.000 pensiones a los familiares de los fallecidos o declarados fallecidos o desaparecidos durante la Guerra Civil o con posterioridad, siempre que se hubiera podido establecer una relación de causalidad personal y directa entre ambos sucesos $^{28}$. Estos datos no están desglosados por fallecimiento o desaparición.

Esta disposición de la Ley 5/1979 estaba pensada especialmente para las viudas de guerra que habían quedado excluidas de las pensiones extraordinarias de viudedad por el régimen franquista. En un país que no tenía establecido un sistema general de pensiones y donde la mujer no se había incorporado todavía masivamente al mundo laboral, sin duda significó una ayuda importante para estas mujeres. Sin embargo, estas pensiones:

1. Se otorgaron sin relación con la condición de víctimas de violaciones de derechos humanos, sin reconocimiento de los hechos ni responsabilidad del Estado ni la presentación de disculpas oficiales.

2. Son claramente asistenciales pues se reconoce la pensión solo a los huérfanos (hombres y mujeres) de padre y madre (en defecto de viuda) que estuvieran incapacitados y a las hijas que se consideraban vulnerables por el hecho de no estar casadas, lo que constituye un claro sesgo de género que ni la Ley 5/2007 ni otra ley posterior han eliminado: el artículo 2 de la Ley 5/1979 sigue reconociendo el derecho a la pensión regulada por dicha Ley «a las viudas, en su defecto los hijos incapacitados, las hijas solteras o viudas y los padres».

3. Los familiares de desaparecidos tuvieron dificultades para solicitar la pensión porque necesitaban copia literal del acta de defunción del causante y, según la Ley sobre el Registro Civil de junio de 1958, la inscripción de una defunción requería un certificado médico (art. 85). En caso de no contar con este certificado, el médico forense debía emitir un dictamen sobre la causa de la muerte, incluso mediante el examen del cadáver, trámites imposibles en caso de desaparecidos de la Guerra Civil

\footnotetext{
${ }^{28}$ Véase p. 43 de dicho informe en: http://www.todoslosnombres.org/content/materiales/informe-generalla-comision-interministerial-para-el-estudio-la-situacion-las (fecha de consulta: 27 febrero 2020). El informe no está publicado en web oficial. La Comisión interministerial fue creada en 2004 por Real Decreto 1891/2004, de 10 de septiembre, por el que se crea la Comisión Interministerial para el estudio de la situación de las víctimas de la Guerra civil y del franquismo (BOE $n^{\circ} 227$, de 20 de septiembre de 2004). Pueden consultarse los datos en un reciente estudio publicado en 2019 que contiene datos requeridos al Ministerio de Hacienda en virtud de la Ley de transparencia, disponible en: https://bit.ly/2kQkeAW (Vallés, 2019).
} 
o la dictadura. Además, el artículo 86 de dicha Ley requería acreditar sin duda alguna el fallecimiento mediante sentencia firme, expediente gubernativo u orden de la autoridad judicial. Para ello, los solicitantes debían justificar documentalmente su derecho y, en caso de no ser posible, se admitía la prueba testifical, cosa también difícil en estos supuestos pues dos personas debían declarar que el desaparecido había fallecido.

En todo caso, cabe insistir en que esta pensión no se contempló en ningún momento como una reparación económica a víctimas de violaciones de derechos humanos o del derecho humanitario, sino como ayudas asistenciales pensadas para personas en una situación considerada vulnerable ante la ausencia del padre de familia: mujeres viudas (no se prevé para viudos aunque sin duda hubo mujeres que fallecieron durante la guerra), huérfanos incapacitados o hijas solteras o viudas, padres de combatientes o civiles republicanos que debían justificar que estaban imposibilitados para ganarse el sustento o bien eran mayores de setenta años, siguiéndose un criterio puramente asistencial ${ }^{29}$.

Por su parte, la Ley 37/1984, de 22 de octubre, de reconocimiento de derechos y servicios prestados a quienes durante la Guerra Civil formaron parte de las Fuerzas Armadas, Fuerzas de Orden Público y Cuerpo de Carabineros de la República, reconoció pensiones a las viudas y huérfanos del personal militar de las fuerzas mencionadas, acentuando así la discriminación entre los hijos de personal civil o militar, por una parte, y los hijos de civiles que sufrieron la represión franquista, por otra, en concreto los civiles desaparecidos durante la Guerra Civil, pues la cantidad y las condiciones de la pensión es diferente.

La Ley 52/2007, de 26 de diciembre, por la que se reconocen y amplían los derechos y se establecen medidas a favor de quienes padecieron persecución o violencia durante la Guerra Civil y la dictadura ${ }^{30}$ (llamada comúnmente "Ley de Memoria Histórica; en adelante, LMH) mejoró en su artículo 5 el importe de las pensiones de viudedad y orfandad previstas en la Ley 5/1979 pero no afectó a los casos de desaparecidos durante la guerra, pues la modificación se refiere al número 2 del artículo primero («los que hubieran fallecido después de la guerra») y la mayor parte de los casos de desaparecidos se produjo durante la guerra. En todo caso, esta modificación no se refiere tampoco a los supuestos de desaparición del apartado Tres del artículo 1, sino a los supuestos a) y c), no al b).

En el artículo 6 de la misma Ley se modificó el importe de las pensiones de orfandad en favor de «huérfanos no incapacitados mayores de veintiún años causadas por personal no funcionario al amparo de las Leyes 5/1979, de 18 de septiembre, y 35/1980, de 26 de junio». Sin embargo, no se modificó la disposición de la Ley $5 / 1979$ por la que prevé que son beneficiarios, en defecto de las viudas, «los hijos incapacitados, las hijas solteras o viudas y los padres» y se desconoce si se sigue aplicando este criterio (solo hijas en esta situación) o bien se aplica la definición de beneficiarios que puede consultarse en la página web del Ministerio de Hacienda y Seguridad Social sobre "Clases pasivas y pensiones derivadas de la Guerra civil»: «El cónyuge viudo y, en su defecto, los huérfanos menores de 21 años o mayores de dicha edad, incapacitados para todo trabajo desde antes de cumplirla o del fallecimiento del causante, y los padres del causante fallecido, siempre que reúnan

\footnotetext{
${ }^{29}$ Real Decreto 2635/1979, de 16 de noviembre para la aplicación y cumplimiento de la Ley 5/1979, BOE $\mathrm{n}^{\circ} 277$, de 19 de noviembre de 1979, p. 26669, artículo 2.c) cuatro.

${ }^{30}$ BOE, núm. 310, de 27 de diciembre de 2007.
} 
las condiciones requeridas por la legislación general sobre Clases Pasivas aplicable en cada caso» ${ }^{31}$.

Este criterio sigue excluyendo a las hijas no incapacitadas solteras o viudas, al no haber modificado la Ley 15/1979 en este aspecto. La información distinta que ofrece la página web del Ministerio de Hacienda refleja la incoherencia y falta de claridad de la normativa que regula las pensiones relacionadas con la Guerra civil, en especial las que podrían beneficiar a familiares de personas desaparecidas. Además, no está actualizada pues no recoge la posterior modificación en la normativa sobre estas pensiones.

Finalmente, es necesario apuntar que desde el 1 de enero de 2013 no es posible obtener ya el reconocimiento de pensiones al amparo de la llamada «legislación de guerra». La Disposición adicional trigésima sexta de la Ley 17/2012, de 27 de diciembre, de Presupuestos Generales del Estado para el año 2013 estableció que a partir de esa fecha no se efectuarían «nuevos reconocimientos de pensiones en favor de huérfanos mayores de veintiún años no incapacitados al amparo de la legislación vigente a 31 de diciembre de 1984, ni de la legislación especial de guerra» ${ }^{32}$. Así, no es posible que un hijo o hija de persona desaparecida durante la Guerra Civil, mayor de veintiún años reclame una pensión de acuerdo con la Ley 15/1979. Sí pueden solicitar pensiones extraordinarias de orfandad, en cambio, los huérfanos a causa de actos de terrorismo, que según la Ley 29/2011, de 22 de septiembre, de Reconocimiento y Protección Integral a las Victimas del Terrorismo será de aplicación a todos aquellos hechos que hayan tenido lugar desde el 1 de enero de 1960, por lo que se trata de una ley retroactiva, además de integral. Esta Ley es un claro ejemplo de cómo España es capaz de atender a víctimas de crímenes muy graves cometidos antes del inicio de la democracia y bajo otro régimen político atendiendo a los principios de respeto, justicia y solidaridad.

Cabe destacar en este apartado que en el Anteproyecto de Ley de Memoria democrática se prevé enmendar este problema con la derogación de la Disposición adicional de 2013 mencionada ${ }^{33}$, pero el hecho es que en todos estos años (20132021) no ha existido esta vía de reparación.

31 Véase esta información en Ministerio de Hacienda: https://www.clasespasivas.sepg.pap .hacienda.gob.es/sitios/clasespasivas/es-ES/PensionesPrestaciones/PrestacionesDerivadasGuerraCivil IPaginas/Familiaresfallecidosenlaguerracivil.aspx. Desde el 1 de enero de 2008 las pensiones de orfandad de huérfanos no incapacitados (sin actualizar desde el año 1981) se revalorizan en el mismo porcentaje que el resto de las pensiones públicas. En 2020, su cuantía está fijada en 159,70 €/ mes.

32 BOE núm. 312, de 28 de diciembre de 2012. Por «legislación especial de guerra» el Ministerio de hacienda comprende desde la Ley de 13 de diciembre de 1943, de pensiones extraordinarias de retiro (para militares afectos al régimen franquista) hasta la Ley 52/2007 «de memoria histórica» y la abundante normativa que la ha desarrollado, pasando por la Ley de amnistía de 1977, las principales leyes de reparación económica (Ley 5/1979 y Ley 35/1980) pero también toda la normativa primero autonómica y después estatal sobre indemnizaciones por tiempo de permanencia en prisión «durante la dictadura» (no durante la guerra) como consecuencia de los supuestos contemplados en la Ley de amnistía, modificados por la Ley 52/2007 «de memoria histórica». Véase una recopilación de esta legislación, a la que se puede acceder desde la página web sobre la Ley de memoria histórica del Ministerio de Justicia (https://www.mjusticia.gob.es/cs/Satellite/Portal/es/areas-tematicas/memoria-historica) en: https://www .clasespasivas.sepg.pap.hacienda.gob.es/sitios/clasespasivas/es-ES/QuienesSomos/Normativa/Colecc ion $\% 20$ Prestaciones $\% 20$ Sociales/Sumario\%20PS02\%20Legislaci\%C3\%B3n\%20especial\%20de $\% 20 \mathrm{gu}$ erra.pdf (fecha de consulta: 27 marzo 2020).

${ }^{33}$ Se incluye en el Anteproyecto de Ley el apartado 2o de su Disposición derogatoria única, derogando expresamente las mencionadas disposiciones adicionales trigésima tercera y trigésima sexta de la Ley de Presupuestos Generales del Estado para el año 2013. En la Memoria del análisis de impacto normativo del Anteproyecto se refiere que esta derogación «tiene un carácter reparador y eminentemente simbólico para los colectivos afectados, y tendrá un impacto económico prácticamente inapreciable, atendiendo a los datos de las últimas indemnizaciones concedidas en los dos últimos ejercicios en los 
Como se ha indicado, en la página web del Ministerio de Hacienda a la que se reenvía desde la página web del Ministerio de Justicia sobre memoria histórica no se informa que desde 2013 no se reconocen nuevas pensiones al amparo de la legislación que recoge la propia web.

En este apartado sobre pensiones concedidas por causa de desaparición durante la Guerra Civil cabría apuntar que, además de la importancia que pueden tener para las víctimas individualmente, en conjunto conocer el número de pensiones concedidas por causa de desaparición durante la Guerra Civil sería un indicio para calcular el número de personas desaparecidas (evidentemente, en uno y otro bando).

Lamentablemente, esta información no es posible obtenerla porque, de acuerdo con la respuesta de la autoridad administrativa competente a una pregunta formulada al Portal de Transparencia del Gobierno de España para recabar datos para realizar este estudio, conocemos que los datos sobre pensiones en virtud de la llamada legislación de guerra no están desglosados por defunción o desaparición. A la pregunta sobre el número de pensiones concedidas al amparo de la Ley 5/1979 y $52 / 2007$ a solicitantes que acreditan la desaparición forzada del causante durante la Guerra Civil y el franquismo, la Unidad de Información de Transparencia del Ministerio de Hacienda responde que ${ }^{34}$

Los datos disponibles en esta Dirección General son los globales, sin distinguir entre los distintos supuestos de hecho contemplados en la norma.

El número de pensiones reconocidas en aplicación de la Ley $5 / 1979$, asciende a 112.968 pensiones (dato actualizado a 31 de diciembre de 2019), y el número de indemnizaciones reconocidas en aplicación de lo dispuesto en el artículo 10 de la Ley $52 / 2007$, es de 49.

2.3. Exhumaciones, censos de desaparecidos de la Guerra civil y homenajes como formas de reparación

Las exhumaciones de fosas relacionadas con la Guerra Civil empezaron durante la misma guerra porque se practicaron judicialmente exhumaciones en la zona republicana entre 1937-1938, mientras que en la zona nacional ya a partir de 1936 se permitió y se reguló exhumar cadáveres y fosas del «bando nacional» (es decir, víctimas de la retaguardia republicana), se facilitó la búsqueda de los desaparecidos del bando nacional y se confeccionó un censo de fallecidos y desaparecidos del bando nacional (Etxeberria, F.; Solé, Q., 2019; Capellà, 2009). En democracia no se ha emprendido hasta ahora un programa nacional de búsqueda de desaparecidos y localización y exhumación de fosas comunes, ni tampoco se ha confeccionado un censo de desaparecidos del bando republicano o un censo global de desaparecidos de la Guerra Civil. Todo esto lo hicieron, paradójicamente, las autoridades franquistas en la inmediata posguerra, pero solamente respecto de las víctimas de las ejecuciones extrajudiciales y desapariciones del bando republicano.

Es necesario conocer el desarrollo de la normativa franquista en materia de inhumaciones, exhumaciones y reinhumaciones para entender el trato desigual que

que estuvieron operativas (años 2012 y 2013), y que, de las 7 solicitudes presentadas en el año 2012, tan solo se concedió 1 , y en 2013 , se presentó una única solicitud que finalmente no fue concedida». Véase Ministerio de la Presidencia, «Memoria de análisis de impacto normativo» (sin fecha), p. 37, en https://www.mpr.gob.es/servicios/participacion/Documents/MAIN\%20APL\%20Memoria\%20Democratic a.pdf (fecha de consulta: 21 enero 2021).

${ }^{34}$ Respuesta de la Unidad de Información de Transparencia del Ministerio de Hacienda $\left(\mathrm{n}^{\circ}\right.$ de expediente 001-040647), de 12 de febrero de 2020. 
sufrieron los familiares de desaparecidos por represión franquista, el desamparo de estos familiares ante la inacción gubernamental treinta años después del final de la dictadura que les llevó abrir fosas a partir de 2000 y a presentar la querella ante la Audiencia Nacional en 2006 por desapariciones forzadas, así como su frustración al ser adoptada la LMH en 2007. De esta inacción del Gobierno español surgen las leyes y políticas autonómicas en esta materia concreta, aunque unos años antes las Comunidades Autónomas (CCAA) ya habían empezado a cubrir graves fallos del sistema español de reparación a las víctimas del franquismo, como las indemnizaciones por tiempo de prisión en la década de 2000, o homenajes y monumentos a las víctimas de la represión franquista.

Justo al acabar la Guerra Civil, en mayo de 1939, se estableció en el BOE el procedimiento por el que toda persona que deseara «exhumar el cadáver de alguno de sus deudos que fueron asesinados por la horda roja, para inhumarlos de nuevo en el cementerio», pudiera solicitarlo del Gobernador Civil de la provincia correspondiente y, tratándose de víctimas del bando franquista, se eximió a los familiares de desaparecidos de pagar tasas municipales de inhumación, exhumación y traslado del cadáver ${ }^{35}$.

Se procedió, asimismo, a elaborar una suerte de censo de personas fallecidas o desaparecidas que no entraban en el supuesto de causantes de las pensiones reconocidas en la legislación de guerra (militares, combatientes, funcionarios civiles, sacerdotes) para «la protección económica de las familias de los caídos en defensa de la Patria que han quedado desamparadas por no reunir las condiciones precisas para disfrutar pensiones de viudedad $u$ orfandad». Era necesario conocer el volumen del problema y por eso se facultó a formular a los familiares de estas víctimas una declaración con los datos del familiar "caído por España», en caso de carecer de pensión concedida por cualquier otro concepto ${ }^{36}$. Los beneficiarios podían ser «las viudas, hijos menores de edad y padres sexagenarios o impedidos para el trabajo» ${ }^{37}$. No se conoce, sin embargo, qué pensiones económicas se llegaron a conceder a los familiares de estas personas en conjunto, al margen de pensiones individuales a viudas de guerra que pueden consultarse en el BOE pero que no parecen seguir un procedimiento legal sino más bien discrecional.

Solo los familiares de las víctimas del bando franquista fueron autorizados a localizar, exhumar y reinhumar los restos de sus allegados enterrados en fosas comunes. Estos familiares recibieron ayudas económicas para llevar a cabo estas tareas y algunas fosas pudieron acotarse y beneficiarse de la misma protección legal que los camposantos ${ }^{38}$. Además, se rindió tributo público a los muertos del bando

\footnotetext{
${ }^{35}$ Véase la siguiente normativa: Orden de 6 de mayo de 1939 y Orden de 1 de mayo de 1940 sobre exhumaciones e inhumaciones de cadáveres de asesinados por los rojos (BOE $n^{\circ} 130$, de 8 de mayo de 1939, p. 3157); Orden aclaratoria de la de 1 de mayo último sobre exhumaciones e inhumaciones de cadáveres de personas asesinadas durante el período rojo (Boletín Oficial del Estado, núm. 207, de 25/07/1940, página 5.151); Orden sobre exhumaciones e inhumaciones de cadáveres asesinados por los rojos (Boletín Oficial del Estado, núm. 130, de 09/05/1940, página 3.157); Ley de 16 de mayo facultando a los Ayuntamientos para dispensar o reducir las exacciones municipales que gravan las inhumaciones, exhumaciones y traslados de cadáveres víctimas de la barbarie roja o muerta en el frente (Boletín Oficial del Estado, núm. 137, de 17/05/1939, páginas 2.687 a 2.688).

${ }^{36}$ Artículo $3 .^{\circ}$ "La declaración deberá contener los siguientes datos: Nombre, apellidos, profesión, estado, edad, y domicilio de la persona que la presente. Nombre del familiar caído por España y su parentesco con el declarante. Número de hijos menores de edad a su cargo. Bienes de fortuna o elementos de Dirección General de la Deuda y Clases Pasivas. Servicios prestados a la Patria por el familiar muerto».

37 Orden de 18 de mayo de 1941, por la que se da plazo para establecer un censo de los familiares de los caídos en defensa de España. Boletín Oficial del Estado, núm. 145, de 25/05/1941, página 3.740.

38 Orden de 4 de abril de 1940, disponiendo que por los Ayuntamientos se adopten medidas que garanticen el respeto a los lugares donde yacen enterradas las víctimas de la revolución marxista, BOE
} 
vencedor, se erigieron monumentos y se hicieron inscripciones dedicadas a los «caídos por Dios y por España» en las fachadas de las iglesias, en las «cruces de los caídos» (en los cruces de caminos o a la entrada de los pueblos) y se construyeron mausoleos en los cementerios para «rendirles honores».

En cambio, en general los familiares de las víctimas de la represión franquista no pudieron desenterrar a los suyos ni les autorizaron a celebrar funerales. Sus nombres no quedaron grabados en las fachadas de las iglesias, en las placas conmemorativas, ni en las cruces de los «caídos». Muchos de ellos, como han documentado los historiadores, ni siquiera pudieron ser inscritos en el registro de defunciones hasta bien entrada la democracia, con todos los problemas que ello conllevó para sus familiares. Con grandes dificultades y riesgos, y asumiendo gastos muy elevados, durante la Transición se exhumaron fosas comunes y se realizaron y aún se realizan (en las comunidades autónomas donde no se han creado instituciones de memoria histórica ni se han adoptado políticas de memoria) lo que se han denominado procesos de "autorreparación» y «autohomenaje», ante la inacción del Estado, la indiferencia de los jueces y la presencia de unas élites políticas mayoritariamente reacias a mirar al pasado (Aguilar, 2018).

Las expectativas creadas en los familiares de desaparecidos tras la declaración de 2006 como «Año de la Memoria Histórica» por el Congreso español quedaron frustradas cuando se presentó el proyecto de ley de lo que después resultó la Ley 52/2007, de 26 de diciembre, por la que se reconocen y amplían los derechos y se establecen medidas a favor de quienes padecieron persecución o violencia durante la Guerra Civil y la dictadura (en adelante $\mathrm{LMH}$ ). Esta frustración se debió, entre otros motivos (Chinchón, 2007; Capellà, 2005; Amnistía Internacional, 2008) a que fue tramitada y adoptada sin consulta ni información a las asociaciones o a familiares de desaparecidos y a que con la LMH la única obligación que asumió el Estado en materia de desapariciones forzadas fue "facilitar» la búsqueda de desaparecidos de la Guerra Civil y la dictadura (artículos 11 a 14). Ello implicó que:

a) La investigación, localización e identificación de las personas desaparecidas recayó en la iniciativa de sus familiares porque el Estado no asumía más obligación que subvencionarlas ${ }^{39}$.

b) El Estado no asumía esta competencia, sino que las exhumaciones de fosas comunes relacionadas con la Guerra Civil y el franquismo se contemplaron en la Ley como una actividad privada a desarrollar bajo la normativa sobre patrimonio histórico (competencia transferida, en general, a las comunidades autónomas), con previa autorización administrativa de la administración pública competente (sin especificar en la LMH cuál es), y cuyos gastos la Administración General debía sufragar con subvenciones (art. 11 in fine).

\footnotetext{
de 5 de abril de 1940 , p. 2320 . Se estableció la obligación de acotar y cerrar aquellos lugares «donde conste de manera cierta que yacen restos de personas asesinadas por los rojos, pero que no han sido identificados o reclamados por sus familiares», solicitar el carácter de tierra sagrada en la misma forma que si se tratase de un nuevo cementerio municipal, e incluso los propietarios particulares de estos terrenos estaban obligados a permitir el uso provisional como cementerios sin derecho a indemnización ni reclamación alguna. Los ayuntamientos disponían de ocho días para iniciar las obras a partir de esta disposición.

${ }^{39}$ Es la conclusión que repetidamente el Comité de Derechos Humanos indica al Gobierno español, la última ocasión en su informe de 2015. Véase: NU doc. CCPR/C/ESP/6, Comité de Derechos Humanos, Observaciones finales sobre el sexto informe periódico de España, 14 de agosto de 2015, párr. 21.
} 
c) Las administraciones públicas no podían poner obstáculos a los particulares y a las asociaciones que pretendieran exhumar fosas por su cuenta, sino que, al contrario, debían facilitar la búsqueda.

d) De acuerdo con la Ley, el Estado debía adoptar un protocolo de actuación científica y multidisciplinar que asegurara la colaboración institucional y una adecuada intervención en las exhumaciones, así como unos mapas de fosas de todo el territorio español que tendrían que debían ser objeto de especial preservación por sus titulares.

La facilitación prevista en la LMH se redujo a subvencionar las exhumaciones por parte del Gobierno central, previa presentación de proyectos a las convocatorias que se sucedieron entre 2006 (hubo dos anteriores a la entrada en vigor de la LMH) y 2011, año en que el presupuesto para la LMH quedó a 0 euros tras cambiar la mayoría política de gobierno en España. Cabe señalar que recientemente el Gobierno español ha reprendido la política de subvenciones, lo cual sería positivo si no fuera porque, como señalan hace tiempo los organismos de derechos humanos, subvencionar las exhumaciones de fosas comunes no constituye una reparación adecuada $^{40}$.

El protocolo previsto en la Ley de 2007 no se adoptó hasta setiembre de 2011 y no se le reconoció carácter vinculante, sino que se trató de una guía metodológica ${ }^{41}$, obviando que los restos humanos encontrados en fosas relacionadas con la Guerra Civil correspondían a muertes violentas y que tenían que ser considerados pruebas de delitos. En caso de localización de restos, dicho protocolo prevé que se comunique tanto a la comunidad autónoma, como a la entidad local, al juzgado de instrucción competente, como a la policía o guardia civil la entidad y características de los hallazgos, pero para el levantamiento de restos no se cuenta con policía forense ni presencia judicial, solo expertos en antropología forense que garantizan la cadena de custodia a efectos de la restitución de los cuerpos identificados.

No se ha realizado un mapa de fosas estatal completo y sobre el estado de los mapas autonómicos de fosas, a marzo de 2020 solo siete comunidades autónomas (CCAA en adelante) habían aportado información a la Dirección General de Memoria Histórica del Gobierno español ${ }^{42}$.

En la práctica, la exhumación de las fosas comunes y la posibilidad de conocer la suerte o el paradero de los desaparecidos de la Guerra Civil y del franquismo

\footnotetext{
40 Según la Dirección General de Memoria Histórica del Gobierno español, ha recibido diez peticiones de financiación por particulares y asociaciones para realizar trabajos de exhumaciones, la mayoría en Andalucía, probablemente ante la suspensión de las políticas de memoria y, en consecuencia, de los planes de fosas, en esta comunidad autónoma. Se trata de exhumaciones de fosas y también de personas inhumadas en cementerios, sin que conste más información. Respuesta del Portal de la Transparencia del Gobierno (expediente 1-040646) a la pregunta «Comunicaciones de solicitudes de exhumación a la Administración General del Estado para su inclusión en el mapa de fosas previsto en artículo 12», de 9 de marzo de 2020.

${ }^{41}$ Orden PRE/2568/2011, de 26 de septiembre, por la que se publica el Acuerdo del Consejo de Ministros de 23 de septiembre de 2011, por el que se ordena la publicación en el Boletín Oficial del Estado del Protocolo de actuación en exhumaciones de víctimas de la Guerra Civil y la dictadura (BOE, núm. 232, de 27 de septiembre de 2011).

42 Respuesta del Portal de la Transparencia del Gobierno (expediente 1-040646) a la pregunta «Comunicaciones sobre datos de los mapas de fosas realizados por las administraciones territoriales y qué administraciones territoriales son (CCAA, municipios)», de 9 de marzo de 2020. Las CCAA que han aportado esta información son Islas Baleares, Castilla y León, Ciudad Autónoma de Melilla, Principado de Asturias, Comunidad Valenciana, Islas Canarias y Comunidad de Madrid.
} 
depende en la actualidad de si una comunidad autónoma ha asumido o no esta competencia, expresamente o implícitamente.

En las comunidades autónomas que no han asumido la competencia específica sobre fosas comunes no se sabe a quién se debe comunicar este hallazgo, ni por razón de la materia (sanidad, cultura) ni por razón de la institución (ayuntamiento, comunidad autónoma, provincia). A la privatización de las labores de exhumación e identificación de los desaparecidos se suma la inseguridad jurídica de una tramitación que encuentra más obstáculos que facilidades, pues las administraciones autonómicas y locales son reacias a adentrarse en unas actividades que no están reguladas y para las que la normativa aplicable -en general la de patrimonio histórico, pues se contempla como una excavación arqueológica- no tiene sentido. Téngase en cuenta que cuando entró en vigor la LMH solo tres comunidades autónomas (País Vasco, Cataluña y Andalucía) habían iniciado políticas de memoria con la creación de comisiones interdepartamentales o comisionados, y que en la actualidad de un total de diecisiete comunidades autónomas solo siete cuentan con leyes autonómicas de memoria histórica y/o de búsqueda de desaparecidos y exhumación de fosas.

El resultado de esta falta de competencia es que las exhumaciones de la Guerra Civil no se han realizado ni se están realizando bajo tutela judicial, a excepción de algunos casos puntuales y, como consecuencia de la jurisprudencia marcada por el Tribunal Supremo en 2012, que se expone en el siguiente apartado, el archivo judicial de las denuncias cuando se encuentran en las fosas restos de personas con signos de violencia en las fosas es sistemático.

Ante el vacío jurídico existente en estas CCAA sin competencia en materia de fosas, las exhumaciones pueden realizarse con autorización administrativa como una excavación arqueológica o como dentro de la política sanitaria mortuoria, en el mejor de los casos, pues en la mayoría de ocasiones no se solicitan autorizaciones administrativas no por falta de voluntad, sino por falta de autoridad competente, tras acudir infructuosamente los familiares o las asociaciones a las posibles instituciones sin obtener una respuesta. La comunicación al juzgado de instrucción competente se lleva a cabo normalmente, pues las asociaciones están interesadas en que haya una intervención judicial, pero pocas veces acude el juez o la policía judicial a levantar acta del hallazgo de restos humanos con signos de violencia en una fosa común de la Guerra Civil, y, si lo hacen, al calcular el año de la inhumación, indican que el hallazgo no tiene interés judicial. Por otra parte, el temor a que la policía o la guardia civil o incluso el juzgado de instrucción competente ordene paralizar los trabajos de exhumación, una vez comunicado el hallazgo de los restos, bien por falta de autorización administrativa al no contar con administración competente, bien por prever una paralización administrativa o judicial de los trabajos de exhumación que pueda afectar el ritmo de la excavación, sume a los equipos de trabajo, a las asociaciones y a los familiares en una situación de preocupación permanente.

La reparación consistente en buscar a las personas desaparecidas y los cadáveres de las personas asesinadas, ayudar a recuperarlos, identificarlos y volver a inhumarlos se ha caracterizado por la inexistencia de un plan o programa nacional y con reconocimiento de los hechos como violaciones manifiestas de las normas internacionales de derechos humanos, y de violaciones graves del derecho internacional humanitario. De hecho, en democracia aún no se ha celebrado a nivel estatal ninguna conmemoración ni ningún homenaje oficial a las víctimas de desaparición forzada de la Guerra Civil que no tuvieron reconocimiento durante la dictadura. A nivel autonómico -no en todas las CCAA- se han adoptado políticas públicas y leyes específicas sobre fosas o sobre «memoria histórica» o «memoria 
democrática» que han desarrollado la obligación de reparación en el aspecto de búsqueda de desaparecidos y localización y exhumación, en su caso de fosas, y se han celebrado homenajes y actos de reconocimiento, pero en ningún caso se contempla reparación económica para las víctimas, en este caso los familiares.

La ausencia de un plan estatal en materia de desaparecidos y fosas comunes ha tenido como consecuencia que los familiares de desaparecidos solo pueden acceder a procedimientos administrativos de carácter público (es decir, sin asumir el coste económico) para esclarecer la suerte y el paradero de las personas desaparecidas y, en su caso, exhumar las fosas comunes correspondientes, en aquellas CCAA donde se encuentra la fosa en la que presuntamente se habría inhumado la persona desaparecida. Con ello se ha creado una grave discriminación entre las familias, porque solo siete de las diecisiete CCAA han asumido esta competencia ${ }^{43}$.

Ante esta discriminación, el Estado aún no ha adoptado medidas adecuadas para garantizar que en el resto de CCAA se realicen estos procedimientos y se espera que la futura Ley de Memoria democrática (aún no iniciada su tramitación como proyecto de Ley en el Congreso, a fecha de enero de 2021) colme este vacío asumiendo el Estado la competencia cuando no exista actuación o política autonómica.

En 2012 el Tribunal Supremo indicó que la vía que el Estado pone a disposición de los familiares de desaparecidos para ejercer un recurso efectivo es la jurisdicción voluntaria (el expediente de perpetua memoria), como se explica en el apartado siguiente, y el Anteproyecto de Ley de Memoria Democrática parece dirigir a los interesados en una exhumación a esta vía jurisdiccional en caso de ser necesario. Ello añade aún más discriminación, porque el coste de una exhumación practicada bajo tutela judicial a instancia de parte en estos procedimientos judiciales corre a cargo de la parte, que es una víctima de violaciones de derechos humanos, con lo que las fosas que se encuentran en un territorio sin ley ni política pública autonómica solo se pueden abrir, en la práctica, a cuenta de la víctima.

Atendiendo a los estándares internacionales en materia de reparación, indicados en la introducción de este estudio, cabe concluir que no solo no se han reconocido, sino que nunca hasta ahora se han verificado los hechos ni se ha procedido a una revelación pública y completa de la verdad. Dos factores dificultan esta misión: por una parte, que el Estado no cuenta con un censo de desaparecidos de la Guerra Civil y la dictadura y, por otra, que los datos que se pueden extraer de los Registros Civiles continúan estando sesgados políticamente a causa de una política institucional iniciada en 1936 que discriminó intencionalmente a los familiares

\footnotetext{
${ }^{43}$ En Cataluña: Ley 10/2009, de 30 de junio, sobre la localización e identificación de las personas desaparecidas durante la Guerra Civil y la dictadura franquista, y la dignificación de las fosas comunes, BOE núm. 186, de 3 de agosto de 2009, páginas 66161 a 66167. En Navarra: Ley foral 33/2013, de 26 de noviembre, de reconocimiento y reparación moral de las ciudadanas y ciudadanos navarros asesinados y víctimas de la represión a raíz del golpe militar de 1936, BOE núm. 304, de 20 de diciembre de 2013, páginas 102302 a 102310. En Baleares: Ley 10/2016, de 13 de junio, para la recuperación de personas desaparecidas durante la Guerra Civil y el franquismo, BOE núm. 157, de 30 de junio de 2016, páginas 46625 a 46632. En la Comunidad Valenciana: Ley 14/2017, de 10 de noviembre, de memoria democrática y para la convivencia de la Comunitat Valenciana, BOE núm. 311, de 23 de diciembre de 2017. En Andalucía: Ley 2/2017, de 28 de marzo, de Memoria Histórica y Democrática de Andalucía. Comunidad Autónoma de Andalucía, BOE núm. 95, de 21 de abril de 2017. En Aragón: Ley 14/2018, de 8 de noviembre, de memoria democrática de Aragón, BOE núm. 14, de 16 de enero de 2019. En País Vasco no tienen ley concreta de memoria histórica, pero realizan políticas y acciones de localización de fosas a través del Instituto de la Memoria, la Convivencia y los Derechos Humanos Gogora, creado en 2014 por Ley 4/2014, de 27 de noviembre, de creación del Instituto de la Memoria, la Convivencia y los Derechos Humanos, Boletín Oficial del País Vasco, n² 230, de 2 de diciembre de 2014.
} 
de desaparecidos por la represión franquista a la hora de realizar las inscripciones de desaparición y de conseguir la declaración de fallecimiento, como se explica en el apartado anterior.

Sin duda fue un avance que por ley se reconociera y declarara el carácter injusto de cualquier forma de violencia personal producida por razones políticas, ideológicas o de creencia durante la Guerra Civil y durante la dictadura (artículo 2 Ley $52 / 2007$ ) pero no se han reconocido estos hechos como violaciones de derechos humanos o del derecho humanitario ni de esta declaración se desprenden consecuencias jurídicas. Tampoco ha habido ni se ha planteado responsabilidad administrativa relacionada con las fosas ni los desaparecidos, por ejemplo, exigiendo responsabilidades a ayuntamientos o a particulares por la destrucción de fosas dentro o fuera de cementerios.

En definitiva, no se ha establecido ninguna medida eficaz hasta el momento para conseguir que no continúe la situación de desaparición forzada y la violación de derechos humanos de las familias de desaparecidos, en concreto el derecho a no ser sometido a tratos crueles e inhumanos, a día de hoy. Las únicas medidas adoptadas a nivel estatal en materia de fosas y desaparecidos han sido impulsadas con la Ley $52 / 2007$, pero no se ajustan a estándares ni a obligaciones internacionales del Estado, pues la principal medida, la facilitación de las exhumaciones mediante subvenciones, no ha seguido ninguna planificación ni evaluación, y supuso, desde el primer día, que el Estado descargó su responsabilidad de localizar y exhumar las fosas comunes en las familias y asociaciones.

Por otra parte, ni los familiares de desaparecidos ni las asociaciones memorialistas participaron en el diseño y ejecución de la LMH: no fueron consultados a pesar de que precisamente en 2007, año de adopción de esta Ley, existía en España un movimiento memorialista ya consolidado que hubiera podido ser un interlocutor eficaz para que tanto las reparaciones simbólicas como la política de exhumación de fosas que se proyectaba fueran valoradas directamente por quienes tenían que ser sus beneficiarios. En cambio, es notorio el rechazo que provocó esta Ley tanto en las asociaciones como en los familiares de personas desaparecidas.

Finalmente, siguiendo también los estándares internacionales, cabría notar que no se han adoptado a nivel estatal medidas de rehabilitación: las víctimas de desaparición forzada (hijos y descendientes de los desaparecidos) no han tenido ni tienen una atención médica ni psicológica ${ }^{44}$ apropiada a su condición de víctimas de desaparición forzada, especialmente por el sufrimiento causado durante años por la falta de noticias sobre el paradero y suerte de la personas desaparecidas, que se transmite de generación a generación; ni su caso se incluye de oficio en su expediente médico (anamnesis) ni se les prestan servicios jurídicos ni sociales en condición de víctimas de desaparición forzada.

\section{Falta de acceso igual a un recurso efectivo}

La Ley 46/1977, de 15 de octubre, de Amnistía ${ }^{45}$ ha sido repetidamente señalada por los organismos internacionales de derechos humanos como la principal causa de que actualmente el ordenamiento jurídico español impida la investigación penal de las

\footnotetext{
${ }^{44} \mathrm{Ni}$ siquiera se contempla con carácter general el acompañamiento psicológico a los familiares durante las exhumaciones. El protocolo estatal de actuación en exhumaciones de víctimas de la Guerra Civil y la dictadura no prevé esta medida. Solo está previsto en las leyes navarra (art. 7.4), balear (art. 7.2), valenciana (art. 9.4) y aragonesa (art. 12.6).

${ }^{45}$ Ley 46/1977, de 15 de octubre, de Amnistía, BOE n² 248, de 17/10/1977. Entrada en vigor el mismo día.
} 
violaciones de los derechos humanos del pasado, en particular los delitos de tortura, desapariciones forzadas y ejecuciones sumarias, aunque hay más motivos, que la Sala Penal del Tribunal Supremo ha enumerado y aplicado en la Sentencia $\mathrm{n}^{\circ}$ 101/2012, causa especial $n^{\circ} 20048 / 2009$, de 27 de febrero de 2012. Diversos estudios jurídicos (Chinchón, 2014; Escudero \& González, 2013; Tamarit, 2014) han analizado esta sentencia especialmente desde la perspectiva de los principios de legalidad e irretroactividad aplicados en relación con el carácter permanente de las desapariciones practicadas a partir de 1936, la naturaleza consuetudinaria de la tipificación internacional de los crímenes contra la humanidad y sus corolarios (imprescriptibilidad, autonomía de la tipificación internacional y prohibición de las amnistías). En este artículo me interesaría profundizar en los recursos que el Tribunal Supremo considera que los familiares de desaparecidos tienen a su disposición para reclamar el derecho a reparación, en este caso la búsqueda y localización de las personas desaparecidas, y valorar si son efectivos en el sentido establecido en los estándares internacionales explicados anteriormente.

Para ello, es necesario tener presente que la Ley de Amnistía interrumpió la consideración legal de las obligaciones del Estado en la responsabilidad por crímenes de distinta naturaleza cometidos en su pasado antidemocrático. Pretendiendo pacificar el proceso de transición en una situación política y social condicionada por los aún afines al régimen franquista, extinguió la responsabilidad penal de las autoridades, funcionarios y agentes del orden público por las conductas criminales realizadas con motivo u ocasión de la investigación y persecución de los actos que el régimen calificaba como actos punibles y de los funcionarios y agentes del orden público por los delitos contra las personas que hubieran podido cometer, además de la responsabilidad por delitos políticos, delitos relacionados con el restablecimiento de las libertades públicas y otros que no podían mantenerse como punibles en un sistema democrático ${ }^{46}$.

Lo que se indica insistentemente al Gobierno español por parte de los órganos internacionales de derechos humanos ${ }^{47}$ es que esta Ley excluyó expresa e intencionadamente el derecho a un recurso efectivo a víctimas de delitos que no han podido ser judicializados en aplicación de esta Ley y en contradicción con las obligaciones internacionales contraídas por España.

Sobre el derecho a un recurso efectivo, ya explicado en la introducción como derecho de las víctimas de violaciones graves de derechos humanos, son un elemento de preocupación en las observaciones del Comité de Derechos Humanos que aplica el Pacto internacional de derechos civiles y políticos ${ }^{48}$ en relación a la naturaleza de la obligación general impuesta a los Estados Partes en el Pacto ${ }^{49}$ en dicho artículo 2.3, a saber: «cada uno de los Estados Partes en el presente Pacto se compromete a garantizar que toda persona cuyos derechos o libertades reconocidos en el presente Pacto hayan sido violados podrá interponer un recurso efectivo, aun cuando tal violación hubiera sido cometida por personas que actuaban en ejercicio de sus funciones oficiales».

\footnotetext{
46 Artículo 2 e) y f) de la Ley.

47 Véase, entre otros: NU doc. CCPR/C/ESP/6, Comité de Derechos Humanos, Observaciones finales sobre el sexto informe periódico de España, 14 de agosto de 2015, par. 21; NU doc. A/HRC/27/49/Add.1, Informe del Grupo de Trabajo sobre las Desapariciones Forzadas o Involuntarias sobre su visita a España (23 a 30 de septiembre de 2013), 2 de julio de 2014, párrs. 37, 39, 43.

${ }^{48}$ La Ley de Amnistía fue adoptada con posterioridad a la ratificación del Pacto internacional de derechos civiles y políticos (27 de abril de 1977) y su publicación en el BOE (30 de abril de 1977). Véase el Instrumento de Ratificación de España del Pacto Internacional de Derechos Civiles y Políticos, hecho en Nueva York el 19 de diciembre de 1966. BOE n 103, de 30 de abril de 1977, páginas 9337 a 9343.

$49 \mathrm{NU}$ doc. CCPR/C/21/Rev.1/Add.13, cit., párr. 15.
} 
Como señala el Comité de Derechos Humanos en el ámbito concreto del Pacto, esta obligación requiere que se «establezcan en el derecho interno mecanismos judiciales y administrativos adecuados para conocer de las quejas sobre violaciones de los derechos». Los mecanismos judiciales permiten garantizar el disfrute de los derechos reconocidos en el Pacto de distintas maneras, en especial mediante la aplicación directa del Pacto, la aplicación de disposiciones constitucionales $u$ otras disposiciones legislativas similares o el efecto de la interpretación del Pacto en la aplicación de la legislación nacional. Por su parte, los mecanismos administrativos pueden dar cumplimiento a la obligación general de investigar las denuncias de violación de modo rápido, detallado y efectivo por organismos independientes e imparciales. En España no se han creado estos mecanismos administrativos $\mathrm{y}$, en cuanto a los judiciales, los familiares de desaparecidos han ejercido como recurso acudir a la vía judicial penal y civil (aunque en mucha menor medida, como se explicará) para reclamar como reparación la investigación de las desapariciones y la exhumación de fosas comunes.

\subsection{La vía penal}

Las querellas presentadas por familiares de desaparecidos y asociaciones memorialistas en diciembre de 2006 ante la Audiencia Nacional pusieron en conocimiento de la Audiencia Nacional los hechos de desaparición y el desconocimiento, hasta la fecha de la denuncia, de la situación de las personas desaparecidas, el lugar de enterramiento y las circunstancias de su fallecimiento. Asimismo, expusieron su derecho a saber y solicitaron la tutela judicial para el descubrimiento de la verdad, la práctica de las actuaciones necesarias y procedentes para la localización e identificación y, si fuera posible, la entrega a sus familiares para testimoniar su respeto y honra. Solicitaron que fuera admitida esta denuncia por crímenes de lesa humanidad de desaparición forzada, y que se practicaran las diligencias interesadas en la denuncia, instruyendo el oportuno proceso penal para la averiguación y punición de los hechos, determinación de las responsabilidades penales, y satisfacción de las civiles a que hubiere lugar.

Es conocido que el caso llegó al Tribunal Supremo, que el 26 de marzo de 2010 , en el marco de las cuestiones de competencia (acumuladas) dictó providencia, acordando suspender el curso del procedimiento hasta que no se resolviera la causa seguida por prevaricación contra el juez instructor. En febrero y marzo de 2012 se conoció el posicionamiento del Tribunal Supremo (TS) sobre la causa iniciada en $2008^{50}$.

De estas resoluciones judiciales me interesa especialmente el Auto de 28 de marzo, y no entraré en el análisis de la Sentencia pues pueden consultarse las opiniones de la doctrina, que en general responden a diferencias en apariencia irreconciliables entre disciplinas jurídicas, por ejemplo, en cuanto a la aplicación retroactiva de la regla de derecho internacional y que pueda afectar a la Ley de amnistía española (en contra: GIL, 2009, pp. 100 y 163; Tamarit, 2011, p. 745). Notemos, sin embargo, que el Tribunal Supremo consideró razonable la pretensión de las víctimas («satisfacer el derecho a saber las circunstancias en las que el familiar respectivo falleció») pero su respuesta fue que esta pretensión «no puede ser dispensada por el sistema penal, pues no es el medio que el legislador ha dispuesto para atender esas legítimas pretensiones», porque, por una parte, es preciso un hecho con apariencia de delito y un posible imputado vivo para iniciar una investigación penal (por ello se juzgó de prevaricación al juez instructor) y, por otra

50 Sentencia $n^{\circ} 101 / 2012$, causa especial $n^{\circ}$ 20048/2009, Tribunal Supremo, Sala de lo Penal, 27 de febrero de 2012. 
«la interpretación de las normas aplicables a los hechos colisiona con la Ley de amnistía de 1977 y los preceptos reguladores de la prescripción, con la determinación de los posibles imputados, y con la subsunción de los hechos en la norma penal que aplica».

En el posterior Auto de 28 de marzo de 2012 el Tribunal Supremo dirigió a los familiares a la vía de la jurisdicción voluntaria que se explica en el siguiente apartado.

Es muy interesante, a efectos de un estudio sobre reparación y recurso efectivo, analizar cómo el Tribunal argumenta que el legislador español optó en la Ley $52 / 2007$ por la vía administrativa para la exhumación de las fosas comunes. Ello, a pesar de que la propia Ley prevé en su Disposición adicional segunda que esta y el resto de previsiones de la Ley «son compatibles con el ejercicio de las acciones y el acceso a los procedimientos judiciales ordinarios y extraordinarios establecidos en las leyes o en los tratados y convenios internacionales suscritos por España», como no podía ser de otra manera si se siguen los estándares internacionales sobre reparación que no excluyen, sino complementan las diferentes formas de reparación. Paradójicamente, un tenor literal de la Sentencia da a entender que la Ley 52/2007 «de memoria histórica» podría haberse convertido en un obstáculo más para que los familiares de desaparecidos puedan obtener reparación por la vía judicial.

En todo caso, y sin posibilidad de extenderme sobre esta cuestión, cabe destacar que en la Sentencia de febrero de 2012 el Tribunal Supremo reconoció expresamente que los familiares de desaparecidos de la Guerra Civil que presentaron denuncia eran víctimas de unos delitos hoy día calificables como delitos contra la humanidad (pero no en España), que estos familiares se encontraban en una situación de objetiva desigualdad respecto a otras víctimas de hechos sustancialmente similares y coetáneos en el tiempo de la Guerra Civil, y, además, que "las leyes y disposiciones posteriores a la Ley de Amnistía, que culminan con la Ley de Memoria Histórica, han reparado, en gran medida, las consecuencias de la guerra y la posguerra, pero no han concluido las actuaciones concretas en orden a la localización y recuperación de los cadáveres para su homenaje y procurar la efectiva reconciliación que la Ley de Amnistía persiguió» ${ }^{51}$.

Es decir, el propio Tribunal Supremo ha reconocido que la reparación no es completa ni adecuada, que la reconciliación que pretendía la Ley de Amnistía no es efectiva y es obvio que, situándonos en el año 2021, la reparación dista de ser lo rápida que exigen los estándares internacionales. El problema, en este punto, está en qué recurso o remedio tienen los familiares de desaparecidos durante la Guerra Civil española para obtener esta reparación, que el Tribunal parece reducir a las tareas de localización y recuperación de las personas desaparecidas obviando otra forma de reparación como la satisfacción, que incluiría entre otros, recordemos, la verificación de los hechos y la revelación pública y completa de la verdad y la aplicación de sanciones judiciales o administrativas a los responsables de las violaciones ${ }^{52}$.

Es en su posterior Auto de 28 de marzo de 2012, cuando el Tribunal Supremo, al resolver la cuestión de competencia, contextualizó la situación de los desaparecidos y de sus familias como «derechos de las víctimas de violaciones de derecho internacional de los derechos humanos y del derecho internacional humanitario» (razonamiento tercero) y donde "considera inobjetable» que los restos de quienes hubieran sufrido muertes violentas no pueden permanecer en el anonimato ni fuera de los lugares propios de enterramiento y que tampoco cabe

\footnotetext{
51 Punto 4 del Considerando sexto.

52 Principios de 2005 sobre recursos y reparaciones, Principio XI, párr. 22.
} 
imponer a sus familiares «el gravamen representado por tal clase de situaciones, moral y jurídicamente insostenibles» (razonamiento cuarto).

Para satisfacer los derechos de estas víctimas, el Tribunal Supremo indica que el ordenamiento vigente arbitra recursos legales a través de los que pueden canalizarse las acciones y exigir, como contrapartida, el deber del Estado de procurar de manera efectiva su satisfacción. El propio Tribunal ya se avanza al considerar que se va a discutir su suficiencia ${ }^{53}$ pero, en la línea de la valoración que hace el Tribunal respecto de las medidas de reparación adoptadas, esta es la opción que ha seguido el Estado para que las víctimas obtengan reparación. Fallaría en este planteamiento el hecho de que las víctimas conocieran las vías apuntadas por el Tribunal en el Auto de marzo y también que las víctimas lo consideraran un recurso efectivo para satisfacer sus pretensiones.

Estos son los recursos que tienen los familiares de desaparecidos para satisfacer su derecho como afectados por tal clase de acciones criminales -que no son perseguibles ni punibles penalmente en España y según el ordenamiento español- a una reparación adecuada, que comprenda a) «la verificación de los hechos y la revelación pública y completa de la verdad», b) «la búsqueda de [...] los cadáveres de las personas asesinadas, y la ayuda para recuperarlos, identificarlos, si fuera necesario, y volver a inhumarlos según el deseo explícito o presunto de la víctima o las prácticas culturales de su familia y comunidad», y c) poder contar con «una declaración oficial o decisión judicial que restablezca la dignidad, la reputación y los derechos de la víctima y de las personas estrechamente vinculadas a ella» (razonamiento cuarto):

- La vía administrativa prevista en la Ley 52/2007, que no excluye, según el Tribunal Supremo, el acceso a la jurisdicción penal excepto si de la propia noticia contenida en la denuncia o querella se deriva la inexistencia de responsabilidad actualmente exigible, es decir, si los presuntos responsables ya han fallecido.

- La jurisdicción civil y, en concreto, los expedientes de jurisdicción voluntaria como el expediente de perpetua memoria (que se explica en el siguiente apartado).

- La inscripción de defunción de desaparecidos introducida por la Ley 20/2011, de 21 de julio, de Registro Civil por la disposición adicional octava, que puede abrir un cauce a la actuación judicial.

La competencia para continuar tramitando las denuncias se trasladó a los juzgados de instrucción territoriales. Estos juzgados (y los que recibieron nuevas denuncias siguiendo el razonamiento de que si había indicios de presuntos responsables vivos, se mantenía abierta la posible vía penal) archivaron los casos basándose en el fallecimiento de los presuntos responsables y también invocando el principio de legalidad, la interdicción de retroactividad de normas procesales, la prescripción, la Ley de Amnistía, y, asimismo, remitiendo a la Ley 52/2007, es decir, aplicando uno o todos los argumentos dados por el Tribunal Supremo en sus resoluciones de febrero y marzo de 2012 (Amnistía Internacional, 2017, p. 9).

\footnotetext{
53 «Al respecto, el ordenamiento vigente arbitra recursos legales a través de los que -por más que su suficiencia se discuta- pueden canalizarse las acciones dirigidas a la satisfacción de los derechos de que se trata».
} 
El resultado de las querellas presentadas en 2006 ha sido que de hecho se ha cerrado la vía judicial penal: solo sería posible en caso de las desapariciones de la Guerra Civil en que los presuntos autores estén vivos, lo cual es poco probable. En mi opinión, esta interpretación y aplicación del derecho español priva a los familiares de personas desaparecidas de ser consideradas víctimas de delitos y contradice estándares internacionales tales como el Principio V de los «Principios y directrices básicos sobre el derecho de las víctimas de violaciones manifiestas de las normas internacionales de derechos humanos y de violaciones graves del derecho internacional humanitario a interponer recursos y obtener reparaciones», según el cual «una persona será considerada víctima con independencia de si el autor de la violación ha sido identificado, aprehendido, juzgado o condenado y de la relación familiar que pueda existir entre el autor y la víctima».

\subsection{La vía civil}

Si bien el Tribunal Supremo mantuvo la imposibilidad del enjuiciamiento penal de los autores de los hechos, por las razones indicadas en el apartado anterior, no excluyó un derecho a recuperar los restos de sus familiares, enmarcado expresamente en el Auto de marzo de 2012 en el deber de los Estados de procurar de manera efectiva su satisfacción de acuerdo con los mencionados Principios de 2005 sobre recursos y reparaciones. Sin embargo, la cuestión es cómo y ante qué órgano pueden invocar este derecho. De entrada, el Tribunal no excluyó cualquier órgano judicial, solamente los de la jurisdicción penal ${ }^{54}$.

Como se ha indicado, las denuncias presentadas en 2006 ante la Audiencia Nacional tenían como objetivo la averiguación y punición de los hechos denunciados, la determinación de las responsabilidades penales y la satisfacción de las civiles a que hubiere lugar. El Tribunal Supremo cerró la vía judicial penal como se ha descrito y no se pronunció sobre las responsabilidades civiles al apreciar que los hechos denunciados no eran punibles.

De las vías apuntadas por el Tribunal Supremo en su Auto de 28 de marzo de 2012 para encaminar a los familiares de desaparecidos hacia la jurisdicción civil, una podría ser eficaz para obtener, sin mayores obstáculos, la declaración de fallecimiento (la inscripción de defunción de desaparecidos introducida por la Ley 20/2011, de 21 de julio, de Registro Civil por la disposición adicional octava), pero no para exhumar una fosa común, por lo que en mi opinión no es efectiva y explico a continuación por qué.

El problema que tienen los familiares de desaparecidos es, como ya se ha indicado, que no existe un plan nacional de búsqueda de personas desaparecidas y localización y exhumación de fosas comunes: la investigación sobre la suerte y paradero de estas personas y la localización y, en su caso, exhumación de una fosa depende de si existe o no una política autonómica que asuma estas tareas. En los territorios en los que no existan unos mecanismos para iniciar y proceder a estas tareas, los familiares tienen como único recurso acudir a la jurisdicción civil, en concreto al expediente de perpetua memoria. Mediante esta vía se ha conseguido al menos una exhumación vía judicial, el de dos víctimas de la represión franquista inhumados en el cementerio del Valle de los Caídos en $1959^{55}$. Considero que el procedimiento seguido en este caso es positivo a efectos del derecho a reparación de

\footnotetext{
54 Siempre con la salvedad: «salvo cuando de la propia noticia contenida en la denuncia o querella se derive la inexistencia de responsabilidad penal actualmente exigible».

${ }^{55}$ Auto 112/2016, de 30 de marzo, del Juzgado de Primera Instancia, Sección 2a , de San Lorenzo de El Escorial, Recurso 851/2014 de 30 de marzo de 2016.
} 
las víctimas, porque la decisión judicial no se limitó a la aprobación y protocolización de información "ad perpetuam memoriam», sino que también autorizó la recuperación de los restos, su entrega por parte del órgano competente a los familiares y la inscripción de su defunción en el Registro Civil. Es decir, el Juez vinculó el procedimiento de publicidad en que consistían las informaciones para perpetua memoria con el derecho a recibir sepultura, y lo ligó a la dignidad propia del ser humano (artículo 10 de la Constitución española).

A pesar de este cambio cualitativo (Escudero, 2018), la argumentación de este Juzgado no se ha aplicado en más casos en el ámbito de la jurisdicción voluntaria y el resultado de este procedimiento en este caso es excepcional, pues se sabía dónde estaban los cuerpos: cuando fueron trasladados al cementerio del Valle de los Caídos se llevó un registro y estaba anotado el número de columbario donde reposaban los restos reclamados, no se trataba de fosas comunes, sino de nichos y, además, solo se exhumaron dos cuerpos y se identificaron con ADN. La realidad de las fosas comunes relacionadas con la Guerra Civil y el franquismo es muy diversa y es difícil afirmar que este procedimiento funcionaría en todos los casos, básicamente porque, para empezar, el procedimiento de perpetua memoria fue derogado por la Ley 15/2015, de 2 de julio, de la Jurisdicción Voluntaria: en concreto, derogó los artículos de la Ley de Enjuiciamiento Civil referidos a las informaciones para perpetua memoria (arts. 2002 y ss.) y este expediente ya no existe expresamente ${ }^{56}$. Se podría entender que se trata de un cambio procesal que no afecta a la norma sustantiva y que se seguiría el procedimiento más generalista, pero hasta ahora no constan casos ni jurisprudencia en este sentido.

Para valorar si este procedimiento se podría volver a utilizar en otros casos y conjeturar si el recurso apuntado por el Tribunal Supremo es efectivo, resulta significativo que el Anteproyecto de Ley de Memoria Democrática prevé la modificación otra vez de la Ley 15/2015 mencionada, para volver a introducir un nuevo título sobre expedientes de jurisdicción voluntaria relativos a declaraciones judiciales sobre hechos pasados ${ }^{57}$. De ello cabe deducir que hay dudas en la actualidad (2021) sobre la eficacia de esta vía tras la derogación de 2015 , porque no existe, pero sigue siendo la vía apuntada por el Tribunal Supremo en 2012.

Además de estas dudas sobre la vigencia -y, por tanto, de la efectividad- del recurso al expediente de perpetua memoria y su aplicación en casos de desaparecidos en fosas comunes en las que no se conozca a ciencia cierta dónde ni cuantas personas están inhumadas, cabe señalar otra característica del procedimiento que no lo hace apto para afirmar que se trate de una reparación adecuada: los costos de las pruebas y de la exhumación, como demuestra el caso de las dos exhumaciones en el Valle de los Caídos explicado, son a cuenta de la parte actora, es decir, de los familiares del desaparecido. Como afirma el Juez en este caso, «la jurisdicción voluntaria no permite que se pueda acordar que un tercero sea el que haga frente al coste de las medidas o derechos reconocidos» ${ }^{58}$. Así, el trato a los familiares es claramente asimétrico, dependiendo de si la fosa se encuentra en una

\footnotetext{
${ }^{56}$ Ley 15/2015, de 2 de julio, de la Jurisdicción Voluntaria, B.O.E. de 3 de julio, vigente desde el 23 de julio. El caso referido al Valle de los Caídos se había iniciado en 2014 por lo que se aplicó la LEC de 1881 al ser la norma vigente cuando se incoó el procedimiento, conforme con la disposición transitoria primera referente a los expedientes en tramitación de la Ley de Jurisdicción Voluntaria 15/2015.

57 Es el mismo texto que el presentado por el Grupo Socialista en el Congreso en julio de 2019, que viene recogido en: Boletín Oficial de las Cortes Generales, Congreso de los Diputados, $n^{\circ} 66-1$, de 30 de julio de 2019. En esta línea, en el Anteproyecto de Ley de Memoria Democrática se pretende introducir en la Ley 15/2015 un nuevo Título IV bis («De los expedientes de jurisdicción voluntaria relativos a declaraciones judiciales sobre hechos pasados») mediante la Disposición final segunda (Modificación de la Ley 15/2015, de 2 de julio, de la Jurisdicción Voluntaria).

58 Auto 112/2016, cit., Razonamiento jurídico quinto, in fine.
} 
comunidad autónoma con competencias y políticas en materia de fosas comunes, pues en este caso los familiares no tienen que asumir el coste de la exhumación.

A ello hay que añadir que no es un procedimiento aplicable cuando los hechos se refieren a pleito pendiente, y muchos de los casos que podrían haber llegado a jurisdicción voluntaria estaban pendientes de los procesos ante los juzgados territoriales tras la inhibición de la Audiencia Nacional, o bien en la actualidad está pendiente la investigación ante la jurisdicción argentina por la vía de la jurisdicción universal. El problema de fondo de este procedimiento se encuentra en el origen del sistema de reparación elegido en su día por el Estado: vuelve a cargar la responsabilidad en los familiares y es posible, además, que surja algún conflicto, no solo entre familiares sino entre Administración y familiares, o bien entre particulares y propietarios de terrenos donde haya una fosa común: en este supuesto, se acabaría la jurisdicción voluntaria.

De aprobarse la reintroducción de los expedientes de jurisdicción voluntaria relativos a declaraciones judiciales sobre hechos pasados mediante una futura Ley de Memoria Democrática cabe tener en cuenta que en el nuevo título propuesto en la Ley $15 / 2015$ se mantienen las condiciones que, como he señalado, pueden ser un obstáculo para esta declaración judicial (que de los hechos sobre los que se interesa la información no resulte perjuicio para una persona cierta y determinada; que los hechos sobre los que se interesa la información no sean objeto de un procedimiento judicial en trámite; que no exista otro procedimiento judicial legalmente indicado para la demostración de los hechos sobre los que se interesa la información) y también para la exhumación de fosas comunes, como recurso efectivo marcado por el Tribunal Supremo en su día para exigir una investigación judicial y una exhumación.

En mi opinión, y a modo de conclusión, en primer lugar entiendo que este recurso judicial no está en vigor en la actualidad, por lo que no existe el recurso judicial efectivo marcado por el Tribunal Supremo: se eliminó en 2015; y, en segundo lugar, considero que las características de la jurisdicción voluntaria la hacen un medio ideal de reparación para un Estado que no está dispuesto a confrontar su pasado ni a establecer responsabilidades, y no garantizan la reparación debida a las víctimas de violaciones de derechos humanos en un sentido integral: en jurisdicción voluntaria no hay pretensión frente a una persona concreta, se solicita la intervención del juez sin estar afectada ni promoverse cuestión alguna entre partes conocidas y determinadas y no hay contradicción o contenciosidad, porque el criterio determinante es la ausencia de conflicto ${ }^{59}$.

Por estos motivos, considero que la jurisdicción voluntaria, en general, no cumple en la actualidad con la obligación de reparar adecuadamente a las víctimas de graves violaciones de derechos humanos. Sin embargo, la novedad de las previsiones del Anteproyecto de Ley de Memoria Democrática es que, si el Estado asume su competencia en materia de localización y exhumación de fosas en las CCAA que no la han asumido hasta ahora, la jurisdicción voluntaria sí que tendría sentido para la obtención de una declaración judicial, una vez la exhumación de una fosa ya no sería objeto de este expediente. Se trataría, así, de una jurisdicción complementaria, y que en todo caso estaría condicionada por las limitaciones comentadas que podrían conducir al archivo del expediente. La cuestión, este punto, es si esto se hace en previsión de que la jurisdicción penal siga cerrada a pesar de

\footnotetext{
${ }^{59}$ La legislación ya derogada preveía que los hechos objeto de información no están limitados siempre que concurran los requisitos: a) que el objeto sea posible; b) que sea lícito; c) que esos hechos no se refieran a pleito pendiente; d) que no resulte perjuicio para persona cierta y determinada; e) que no exista otro procedimiento distinto ordenado por la Ley para su demostración.
} 
los cambios que introduciría la nueva Ley, que se explican a continuación.

\section{Iniciativas legislativas de ámbito estatal}

Entre 2017 y 2020 se han presentado diversas proposiciones de ley en materia de memoria histórica en el Congreso de los Diputados. Su número se explica por el hecho de que han decaído al convocarse elecciones generales y disolverse el Congreso, pero se han vuelto a presentar, por una parte; y, por otra, en que los diferentes grupos parlamentarios de izquierdas no se han puesto de acuerdo en presentar una propuesta común y, de hecho, han votado en contra de las otras proposiciones presentadas. Estas iniciativas tienen puntos en común, otros claramente opuestos.

Así, por ejemplo, la Proposición de Ley de memoria histórica y democrática que presentó el Grupo Parlamentario Socialista en enero de 2020 no contemplaba ninguna previsión en materia de justicia ni tampoco la derogación parcial de la Ley de Amnistía en los aspectos incompatibles con el derecho a un recurso efectivo de las víctimas del franquismo, incluyendo los familiares de desaparecidos ${ }^{60}$. Sin embargo, en 2017 el propio Grupo Parlamentario Socialista había presentado una proposición de ley ${ }^{61}$, estando en la oposición, que preveía la competencia de los órganos judiciales competentes en el orden penal en la búsqueda de los desaparecidos, el principio de reparación como principio informador de la búsqueda judicial de desaparecidos (y no meramente el principio de punición) y la responsabilidad del Estado en la búsqueda de los desaparecidos, entre otras medidas que, lamentablemente, "desaparecieron» de sus iniciativas legislativas una vez el PSOE asumió el Gobierno en junio de 2018 hasta enero de 2020, con lo que la proposición de ley está visiblemente recortada.

Por su parte, el Grupo Parlamentario Confederal de Unidos Podemos-En Comú Podem-En Marea, que en la actualidad (enero de 2021) gobierna junto con el Partido Socialista Obrero Español (PSOE), presentó en 2018 una Proposición de Ley integral de memoria democrática y de reconocimiento y reparación a las víctimas del franquismo y la Transición que sí recogía la nulidad de los epígrafes e) y f) del artículo 2 de la Ley de Amnistía que cubren de impunidad los crímenes del franquismo ${ }^{62}$. El Grupo Parlamentario Socialista votó en contra. La última proposición de ley presentada, al cierre de este artículo, es la Proposición de Ley de reconocimiento y protección integral a las víctimas del franquismo y de la memoria democrática del Estado español ${ }^{63}$, del Grupo parlamentario de izquierda confederal, en abril de 2020.

Destaca de estos textos un enfoque general de derechos humanos y la consideración de las víctimas del franquismo como víctimas de violaciones graves de

\footnotetext{
${ }^{60}$ Registro general de entrada 0006526, de 24 de enero de 2020. Es el mismo texto que el presentado en julio de 2019, recogido en: Boletín Oficial de las Cortes Generales, Congreso de los Diputados, $n^{\circ} 66-$ 1, de 30 de julio de 2019.

${ }^{61}$ Proposición de Ley $n^{\circ}$ 122/000157 para la reforma de la Ley 52/2007, de 26 de diciembre, por la que se reconocen y amplían derechos y se establecen medidas en favor de quienes padecieron persecución o violencia durante la Guerra Civil y la dictadura, presentada por el Grupo Parlamentario Socialista. Boletín Oficial de las Cortes Generales, Congreso de los Diputados, n 190-1, de 22 de diciembre de 2017.

62 Disposición adicional primera. Nulidad epígrafes e) y f) del artículo 2 de la Ley 46/1977 de Amnistía. Se declara la nulidad de los epígrafes e) y f) del artículo 2 de la Ley 46/1977, de 15 de octubre, de Amnistía por ser contraria al derecho internacional, concretamente respecto a la imprescriptibilidad y prohibición de amnistía de los crímenes internacionales como son los crímenes de lesa humanidad y el genocidio. Boletín Oficial de las Cortes Generales, Congreso de los Diputados, $n^{\circ} 317-1$, de 15 de octubre de 2018.

${ }^{63}$ Registro general de entrada 24.510, de 21 de abril de 2020.
} 
derechos humanos. Sin embargo, se echó en falta y sin duda defraudó a las asociaciones memorialistas y a los familiares de víctimas que en su momento los grupos parlamentarios proponentes de las tres propuestas legislativas fueran incapaces de ponerse de acuerdo, por ejemplo, en la cuestión de la derogación de parte de la Ley de Amnistía.

Por su parte, el Gobierno español presentó en setiembre de 2020 un Anteproyecto de Ley de Memoria Democrática del que cabe apreciar el intento por adecuar la normativa española a las obligaciones y estándares internacionales de derechos humanos y garantizar los derechos a la verdad, a la justicia y a la reparación de las víctimas del franquismo y en especial de las víctimas de desaparición forzada. Sin duda constituirá un gran avance si se aprueba la propuesta de crear una Fiscalía de Sala de Memoria Democrática y Derechos Humanos (artículo 29) con las funciones previstas en la Disposición final primera (Modificación de la Ley 50/1981, de 30 de diciembre, por la que se regula el Estatuto Orgánico del Ministerio Fiscal) ${ }^{64}$, el reconocimiento del derecho de las víctimas a la verdad (artículo 14), la articulación de un Plan de Memoria Democrática cuatrienal (artículo 12) y toda la sección dedicada a la localización e identificación de personas desaparecidas (artículo 15 y siguientes), que incluye la asunción de competencia por parte de la Administración General del Estado y la obligación de poner en conocimiento del Ministerio Fiscal los hallazgos de restos de exhumaciones. Especialmente revelador de la intención de avanzar en los aspectos que desde órganos internacionales se señalan a España en relación con los derechos de las víctimas del franquismo es la previsión de que «una persona será considerada víctima con independencia de que exista o no autoría conocida de la violación de sus derechos", en el Título I sobre las víctimas, y que "se garantizará la tutela judicial en los procedimientos encaminados a la obtención de una declaración judicial sobre la realidad y las circunstancias de hechos pasado relacionados con las víctimas» en el Capítulo II titulado «De la justicia». En la línea de lo que he expuesto en el apartado anterior, parece que esta declaración judicial sería en el ámbito de la jurisdicción voluntaria, con los obstáculos y las posibles contradicciones que se han señalado.

A pesar de estos puntos positivos, algunas disposiciones chirrían en el documento presentado, como el recordatorio a los poderes públicos de que cuando se apruebe la ley deberá ser interpretada «de conformidad con los tratados internacionales de derechos humanos en la materia ratificados por España, sin perjuicio de su aplicación directa cuando correspondiera» (artículo 2.1 sobre Principios generales), como si las anteriores (Ley 46/1977 de Amnistía, Ley 52/2007 "de memoria histórica») no lo tendrían que haber sido ya sin necesidad de una disposición legal específica. También extraña el hecho de incluir en el Censo nacional de Víctimas (artículo 9.2) como tales a quienes murieron en combate durante la Guerra Civil, en contradicción con el concepto general de víctima, el hecho de no mencionar expresamente las reparaciones económicas entre el contenido de una reparación integral a las víctimas (artículo 31). Como se ha indicado en el apartado anterior, en el Anteproyecto también se propone reintroducir en la Ley 15/2015 el título sobre expedientes de jurisdicción voluntaria relativos a declaraciones judiciales sobre hechos pasados, manteniendo la vía marcada por el Tribunal Supremo de la jurisdicción voluntaria como vía judicial para obtener reparación y una investigación judicial. En todo caso, se trata aún de un Anteproyecto que no ha iniciado su tramitación parlamentaria y no es pertinente aún un análisis pormenorizado.

\footnotetext{
${ }^{64}$ Como la función (f) «Coordinar la acción del Ministerio Fiscal en materia de interpretación de la jurisprudencia del Tribunal Europeo de Derechos Humanos, en especial en aquello que pudiera afectar a los recursos de revisión de sentencias en por esta materia. Asimismo, será el cauce de relación y coordinación entre la Fiscalía del Tribunal Supremo y la Fiscalía ante el Tribunal Constitucional».
} 
Quisiera notar, no obstante, que el actual Anteproyecto, en mi opinión, parte de un problema de fondo y de enfoque, pues plantea las violaciones de derechos humanos en el pasado y con fecha límite (la entrada en vigor de la Constitución española de 1978) cuando estas violaciones se han producido y se están produciendo jurídicamente desde esa precisa fecha, en concreto desde la ratificación por parte de España de los primeros tratados de derechos humanos, como el Pacto Internacional de Derechos Humanos en 1977 y el Convenio Europeo de Derechos y Libertades Fundamentales en 1979. Era a partir de ese momento en que el Estado incumplió sus obligaciones internacionales, en especial con la Ley de Amnistía, y el hecho de que el Anteproyecto no plantee la derogación de la parte que obstaculiza la punibilidad de crímenes cometidos tanto durante la Guerra Civil como durante la dictadura es un motivo de preocupación y de duda en cuanto a la eficacia y especialmente las esperanzas depositadas en la futura Ley de Memoria Democrática, al menos en este aspecto.

\section{Conclusiones}

España no garantiza ni la verdad ni la justicia en relación con las víctimas de desaparición forzada de la Guerra Civil y el franquismo, y solo parcialmente la reparación.

Como observaba el anterior Relator Especial sobre justicia de transición tras su visita a España en 2014, las autoridades españolas no niegan la legitimidad de las pretensiones de los familiares de desaparecidos pero «la mayoría de las autoridades, con uniformidad casi absoluta, han argumentado que la vía de la investigación penal no es un cauce adecuado para hacer efectivo el derecho a la verdad, que la función de la acción penal es imponer una sanción a los responsables y que ante la imposibilidad de identificar un supuesto responsable o la presunción de su muerte, se extinguiría toda pertinencia de una investigación judicial» (Relator Justicia Transicional, 2014, p. 13). ¿Cuándo pasará de ser una pretensión legítima a tener el reconocimiento legal que existe en derecho internacional y en otros países? En el actual Anteproyecto de Ley de Memoria Democrática se proponen diversas vías para abrir la vía penal, sin mencionar expresamente la situación jurídica de desaparecidos, y habrá que ver si estos cambios legislativos impulsan un cambio judicial.

En mi opinión, para hacer exigible el derecho a la justicia se tendrá que hacer un gran esfuerzo doctrinal y judicial en el ámbito penal para conseguir los cambios que hace años instan los órganos internacionales y reclaman las víctimas y las asociaciones, y que también propone el Anteproyecto de Ley de memoria Democrática. Para volver a abrir la vía penal en España, veo más probable que la querella argentina provoque en algún momento que los tribunales españoles instruyan los casos para que sean investigados en España y no en Argentina en virtud de la jurisdicción universal vigente en ese país, a raíz de otro cambio anunciado desde la Fiscalía General del Estado ${ }^{65}$. De la vía marcada por el Tribunal Supremo en 2012 sobre los expedientes de perpetua memoria, los casos que han llegado a la vía de la jurisdicción voluntaria son escasos y la reforma de 2015 de la Ley de jurisdicción voluntaria cerró la vía abierta en 2016 ante el juzgado de El Escorial.

Para garantizar el derecho a la reparación, emprender el tan reclamado plan nacional de reparaciones es una prioridad, pero para ello se tendrá que tener en

\footnotetext{
${ }^{65}$ En agosto de 2020 la Fiscal General dejó sin efecto una orden firmada por su antecesora en el cargo, de septiembre de 2016, en la que se instaba al fiscal jefe de Madrid a oponerse a la tramitación de comisiones rogatorias relacionadas con la causa abierta en Argentina por crímenes franquistas entre 1976 y 1978.
} 
cuenta que no hay datos fiables sobre la cantidad y la identidad de las personas desaparecidas porque, como he explicado a lo largo de este estudio, las inscripciones de desaparición en los registros civiles están sesgadas ideológicamente y las pensiones a familiares de desaparecidos no cuentan con datos desglosados atendiendo la situación del causante.

Por otra parte, he explicado también el trato desigual que se infligió a los familiares de personas civiles desaparecidas por represión franquista a partir de la tramitación de la inscripción de las desapariciones en los registros civiles, diferenciando a las víctimas de desaparición por la causa de la desaparición y cómo esta diferenciación ha resultado discriminatoria para sus familiares no solo durante la guerra y la dictadura franquista, sino también hasta nuestros días. Es posible que un hijo o hija de desaparecido por represión franquista no haya tenido la oportunidad de solicitar ni cobrar una pensión de huérfano mientras la hayan cobrado los huérfanos de guerra contemplados en la normativa franquista. Así, por ejemplo, los hijos de desaparecidos por represión franquista no pudieron acceder a las pensiones de huérfanos, creadas en 1940, porque no eran huérfanos legalmente. O bien una hija de persona desaparecida por represión franquista no podría haber solicitado pensión de orfandad con la Ley 5/1979 porque esta discriminaba a las mujeres casadas, solo las solteras podrían haberla conseguido. No es posible saberlo mientras no se desglosen los datos sobre pensiones y podamos comprobar cuántas personas han solicitado estas pensiones y la situación del causante (desaparecido). Este desglose no solo serviría a estos efectos sino también para responder a las reticencias que se suelen poner oficiosamente a la reclamación de reparar económicamente a los familiares de desaparecidos, al considerarse que será una cantidad inasumible para las arcas del Estado, pues hasta que no exista un censo oficial, riguroso y específico de personas desaparecidas, no será posible calcular el coste total de estas pensiones o indemnizaciones.

En mi opinión, el Estado ha adoptado y previsto medidas legislativas a partir de la Transición hasta nuestros días (Ley 5/1979, Ley 52/2007, Disposición adicional octava de la Ley 20/2011, de 21 de julio, del Registro Civil), judiciales (Sentencias del Tribunal Supremo y sentencias de las jurisdicciones territoriales) y administrativas (reconocimiento personal, mapa de fosas, exhumaciones en CCAA con competencia) en relación con las víctimas de desaparición forzada, pero no son apropiadas, pues el resultado es claramente insuficiente para las víctimas e ineficaz a efectos del objetivo de dar reparación. Además, no son acordes con los estándares internacionales ni tampoco con las obligaciones internacionales asumidas por España, porque, a mi juicio, ha habido desarrollos normativos importantes a nivel internacional que no están siendo aplicados a estas víctimas, negándoles de forma discriminatoria el derecho a un recurso efectivo para exigir reparación respecto de otras víctimas de violaciones graves de derechos humanos.

Los familiares de personas civiles desaparecidas por represión franquista no han obtenido una reparación adecuada, efectiva y rápida del daño sufrido como familiares de víctimas de violaciones graves de derechos humanos, y en concreto por el trato inhumano y cruel infligido por acción y por omisión a las familias de desaparecidos durante la guerra y la dictadura. Después, tampoco la han obtenido en democracia debido, en primer lugar, a la falta de reconocimiento de estos familiares como víctimas de desaparición forzada, con todo lo que comporta: deberían ser tratadas como víctimas de delitos, equiparables a otras víctimas de delitos muy graves como las víctimas de terrorismo, que sí cuentan con un plan integral y nacional de reparación, y respecto de las cuales el Estado se subroga en la responsabilidad civil de los autores de los delitos cuando no es posible que respondan por ellos civilmente. En segundo lugar, no existe en la actualidad un recurso accesible, efectivo y mucho 
menos rápido a nivel nacional (lo cual a estas alturas es urgente dada la avanzada edad de los hijos de desaparecidos que puedan ejercer este recurso) para reivindicar sus derechos, en concreto el derecho a reparación económica y el derecho a saber la suerte o el paradero de las personas desaparecidas y a recuperar sus restos.

Estas carencias son conocidas internacionalmente. Recientemente (febrero de 2021) a raíz de una comunicación relacionada con la desaparición forzada de dos personas durante la Guerra Civil en Mallorca, el Comité de Derechos Humanos -a pesar de no admitirla a trámite por falta de competencia temporal-, ha reconocido «el profundo sufrimiento, angustia y estrés causados por la desaparición forzada de sus familiares y por la actitud de indiferencia mostrada por el Estado parte frente a las reiteradas solicitudes de las autoras durante diversas décadas por la verdad y la justicia» ${ }^{66}$.

Es necesario un enfoque de derechos humanos más claro, definir quiénes fueron "víctimas» desde esta perspectiva, articular una política integral de reparaciones sin precondiciones y, sobre todo, establecer el reconocimiento de la responsabilidad del Estado ante la indefensión y el desamparo de las víctimas de desaparición forzada de la Guerra Civil y el franquismo, en el pasado y también en el presente.

Bibliografía

Aguilar, P. (2018). Memoria y transición en España. Exhumaciones de fusilados republicanos y homenajes en su honor. Historia y Política, 39, pp. 291-325.

Amnistía Internacional (2008). España: La obligación de investigar los crímenes del pasado y garantizar los derechos de las víctimas de desaparición forzada durante la Guerra civil y el Franquismo, Índice EUR410008-20809, 31 de noviembre de 2008.

Baylos, A. (2008). Derechos económicos e indemnizaciones derivados de la memoria histórica. En Martín Pallín, J.A; Escudero Alday, R. Derecho y memoria histórica (pp. 185-208). Madrid, España: Ed. Trotta.

Capellà Roig, M. (2005). Las desapariciones forzadas en España durante la Guerra civil: crímenes y violaciones de derecho internacional sin castigo ni reparación. En Soroeta, J. (ed.). Conflictos y protección de derechos humanos en el orden internacional. Cursos de Derechos Humanos de Donostia-San Sebastián, , volumen VI (pp. 265-303). San Sebastián, España: Servicios Editoriales de la Universidad del País Vasco.

Capellà Roig, M. (2009). Situación jurídica de los desaparecidos y de las fosas comunes en España en relación con la Guerra civil y la represión franquista. En A. Segura; A. Mayayo, Q. Solé, Fosas comunes y simbología franquista ( pp. 237247). València, España: Ed. Afers.

Chinchón Alvarez, J. (2007). El viaje a ninguna parte: Memoria, leyes, historia y olvido sobre la Guerra civil y el pasado autoritario en España. Un examen desde el derecho internacional, 45 Revista del Instituto Interamericano de Derechos Humanos (2007)

Chinchón Álvarez, J.; Vicente Márquez, L.; Moreno Pérez, A. (2014). La posición del Tribunal Supremo respecto a la aplicación del derecho internacional a los crímenes del pasado en España: Un análisis jurídico tras los informes del Grupo de Trabajo sobre Desapariciones Forzadas, el Comité contra la Desaparición

\footnotetext{
${ }^{66}$ NU doc. CCPR/C/130/D/3599/2019, Decisión aprobada por el Comité a tenor del artículo 5, párrafo 4, del Protocolo Facultativo, respecto de la comunicación núm. 3599/2019, de 10 de febrero de 2021, párr. 7.7.
} 
Forzada y el Relator Especial sobre Justicia Transicional de las Naciones Unidas. Anuario Interamericano de Derecho Internacional Penal, Bogotá, pp. 66-101.

Escudero Alday, R.; Pérez González, C. (eds.) (2013), Desapariciones forzadas, represión política y crímenes del franquismo. Madrid, España: Trotta.

Escudero, R. (2018). Memoria histórica e imperio de la ley: el poder judicial ante el derecho a la reparación de las víctimas del franquismo. Derechos y Libertades. Número 38, Época II, pp. 73-105.

Etxeberria, F.; Solé, Q. (2019). Fosas comunes de la Guerra civil en el Siglo XXI: antecedentes, interdisciplinariedad y legislación. Historia Contemporánea, 2. pp. 401-438.

Gil, A. (2009). La Justicia de transición en España, Madrid, España: Dikynson.

International Comission of Jurists (2018). The Right to a Remedy and Reparation for Gross Human Rights Violations. A Practitioners' Guide. Revised Edition. Recuperado de https://www.icj.org/wp-content/uploads/2018/11/Universal-Rightto-a-Remedy-Publications-Reports-Practitioners-Guides-2018-ENG.pdf,

Ministerio de la Presidencia, Relaciones con las Cortes y Memoria Democrática de España (2020). Anteproyecto de Ley de Memoria Democrática. Madrid, España. Recuperado de: https://www.mpr.gob.es/servicios/participacion/Documents/ APL\%20Memoria\%20Democrática.pdf?fbclid=IwAR1kK79f5yM1vD1xDgyhm2D YvLy6X2xL0a6VOJeDrLE GsRQo8MIL2jgRNc (fecha de consulta, 15 enero 2021).

Naciones Unidas (2014), Consejo de Derechos Humanos, Informe del Relator Especial sobre la promoción de la verdad, la justicia, la reparación y las garantías de no repetición, Pablo de Greiff: Misión a España, 22 Julio 2014, A/HRC/27/56/Add.1.

Pisillo Mazzeschi, R. (2003). Reparation Claims by Individuals for State Breaches of Humanitarian Law and Human Rights: An Overview. Journal of International Criminal Justice 1, pp. 339-347.

Shelton, D. (2005). Remedies in International Human Rights Law. 2d ed. Oxford, Reino Unido: Oxford University Press.

Tamarit Sumalla, J.M. (2011). Transition, Historical Memory and Criminal Justice in Spain, Journal of International Criminal Justice, 9, pp. 729-752.

Tamarit Sumalla, J.M. (2014). Memoria histórica y justicia transicional en España: el tiempo como actor de la justicia penal. Anuario Interamericano de Derecho Internacional Penal, vol. 2, pp. 43-65.

Vallès, D. Las reparaciones económicas por los daños derivados de la Guerra civil española y del franquismo. Pamplona, España: Thomson Reuters Aranzadi. 